\title{
Refining Species Traits in a Dynamic Vegetation Model to Project the Impacts of Climate Change on Tropical Trees in Central Africa
}

\author{
Marie Dury ${ }^{1, *}$, Lenni Mertens ${ }^{1,2}$, Adeline Fayolle ${ }^{3}$, Hans Verbeeck ${ }^{4}{ }^{\oplus}$, Alain Hambuckers ${ }^{2}$ (D) \\ and Louis François 1 (D) \\ 1 Modélisation du Climat et des Cycles Biogéochimiques, UR SPHERES, University of Liège, Quartier Agora, \\ Bât. B5c, Allée du six Août 19c, 4000 Liège, Belgium; lennimertens@gmail.com (L.M.); \\ Louis.Francois@uliege.be (L.F.) \\ 2 Biologie du Comportement, UR SPHERES, University of Liège, Quai Van Beneden 22, 4020 Liège, Belgium; \\ Alain.Hambuckers@uliege.be \\ 3 Gestion des Ressources Forestières, TERRA Teaching and Research Centre, Gembloux Agro-Bio Tech, \\ University of Liège, Passage des Déportés 2, 5030 Gembloux, Belgium; adeline.fayolle@uliege.be \\ 4 Computational and Applied Vegetation Ecology (CAVElab), Ghent University, Coupure Links 653, \\ 9000 Ghent, Belgium; hans.verbeeck@ugent.be \\ * Correspondence: Marie.Dury@uliege.be; Tel.: +32-4-366-97-23
}

Received: 24 October 2018; Accepted: 16 November 2018; Published: 20 November 2018

\begin{abstract}
African tropical ecosystems and the services they provide to human society suffer from an increasing combined pressure of land use and climate change. How individual tropical tree species respond to climate change remains relatively unknown. In this study, we refined the species characterization in the CARAIB (CARbon Assimilation In the Biosphere) dynamic vegetation model by replacing plant functional type morpho-physiological traits by species-specific traits. We focus on 12 tropical tree species selected for their importance in both the plant community and human society. We used CARAIB to simulate the current species net primary productivity (NPP), biomass and potential distribution and their changes in the future. Our results indicate that the use of species-specific traits does not necessarily result in an increase of predicted current NPPs. The model projections for the end of the century highlight the large uncertainties in the future of African tropical species. Projected changes in species distribution vary greatly with the general circulation model (GCM) and, to a lesser extent, with the concentration pathway. The question about long-term plant response to increasing $\mathrm{CO}_{2}$ concentrations also leads to contrasting results. In absence of fertilization effect, species are exposed to climate change and might lose $25 \%$ of their current distribution under RCP8.5 (12.5\% under RCP4.5), considering all the species and climatic scenarios. The vegetation model projects a mean biomass loss of $-21.2 \%$ under RCP4.5 and $-34.5 \%$ under RCP8.5. Potential range expansions, unpredictable due to migration limitations, are too limited for offsetting range contraction. By contrast, if the long-term species response to increasing $\left[\mathrm{CO}_{2}\right]$ is positive, the range reduction is limited to $5 \%$. However, despite a mean biomass increase of $12.2 \%$, a positive $\mathrm{CO}_{2}$ feedback might not prevent tree dieback. Our analysis confirms that species will respond differently to new climatic and atmospheric conditions, which may induce new competition dynamics in the ecosystem and affect ecosystem services.
\end{abstract}

Keywords: tree species; traits; tropical Africa; climate change; ecosystem services; dynamic vegetation model 


\section{Introduction}

African tropical forests experience increasing pressure under the influence of land use and climate change, resulting in substantial area reduction and degradation. Consequently, the sustainability of tropical forest ecosystems and the wide range of services they provide to human society are at risk.

Land use change is mainly triggered by a seemingly inexorable population growth, generating a continuously growing demand for food and space [1,2]. Urban expansion affects vast areas beyond city boundaries by import of agricultural and forest products [3], while the still dominant system of production, slash-and-burn agriculture, is no longer sustainable because the fallow period between different phases is greatly reduced or even skipped. Other direct human threats to these ecosystems include the expansion of pastures [4] and roads [5], illegal or poorly managed logging [6] and the rapid expansion of biofuel production [7]. These dynamics reduce biodiversity and expose urban surroundings to savannization or even soil erosion [8,9]. In central and West Africa, the forest has been reduced by $4 \%$ from 2000 to 2010 and by $2 \%$ more from 2010 to 2015 [10]. The remaining forest is characterized by increasing fragmentation and by use of protected area resources [11-13]. The reduction of forest cover at landscape level may also alter tree species composition and functionality [14], for instance, by the replacement of highly specialized taxa by more common local species taking advantage of the proliferation of fire-degraded, drier or more illuminated areas as observed in the Neotropics $[15,16]$. Although such degradations of forest cores are much subtler than the deforestation and degradation observed around cities, they will also considerably alter ecosystem services (ES) in the future.

Yet, increasing evidence from Africa indicates changes in distribution and phenology of species and ecosystem perturbations exceeding those induced by direct human pressures [17]. This evidence points to effects of climate change on vegetation, putting at risk of extinction those species unable to respond adequately $[18,19]$. Although it is difficult to determine the role of climate change in isolation from the other drivers because of important interacting effects [20], the impact of future climate change on ecosystems and individual species should be investigated to assess resilience. If resilience is affected by climate change, vulnerability to anthropogenic pressures may increase. Furthermore, by deepening our understanding of how climate change might alter landscapes, we can improve our efforts to mitigate those effects [21]. Following the call for more studies on the response of African ecosystems to future climate change [22-27], the number of studies is now rapidly growing. They confirmed the risk of increasing ecosystem vulnerability in, for instance, Congo Basin region [28], South Africa [21,29], West Africa [30] and intertropical Africa [31]. Other studies warn of an increasing species vulnerability in, for instance, Namibia [32], East Africa [33], West Africa [34], Cape region [35], eastern Morocco [36], Algeria [37] and Tunisia [38] when they experience increased water and temperature stress.

Nonetheless, these studies, when the analysis is led at the species level, are for the most part performed with environmental niche-based models (ENMs). These models have widely acknowledged limitations (e.g., [39]) that are mostly derived from the hypothesis of uniformitarianism. Indeed, since ENMs rely on empirical relationships between environmental variables and observed species occurrence or abundance to predict future situations, they are unable to take some crucial factors into account. For instance, these models neglect ecosystem response times under the transient climatic evolution, they are ineffective to take $\mathrm{CO}_{2}$ fertilization and its potential impacts on the carbon and water budgets into account, and they describe the biotic interactions only implicitly. Dynamic vegetation models (DVMs), on the contrary, are process-based, enabling them to solve several difficulties encountered by ENMs, particularly the transient conditions, the $\mathrm{CO}_{2}$ fertilization and, in some way, the competition between plants for space and resources [40].

Whereas DVMs are already used for African ecosystem analysis (e.g., [29,41,42]), there is no application on individual species, to the best of our knowledge. Large-scale process models that describe the impacts of climate change on ecosystems generally use the concept of plant functional types (PFTs), which, for tropical forests, are generally very broad classes of plants. So, these models can only provide a very general response of tropical ecosystems to climate change while individual species 
with so particular worth showed specific responses to past environmental changes [43]. Moreover, with narrower bioclimatic spectrum than PFTs, individual species may prove to be more vulnerable to climate change. The difficulty of DVM application on individual species resides in the importance of specific morpho-physiological traits for optimal model performance [39]; yet, many traits of African tropical tree species remain unknown [44].

In this contribution, we address two questions. First, what is the relevance of using morpho-physiological traits specific to species instead of traits characterizing PFTs? Secondly, what could be the magnitude of tree species responses to climate change in equatorial Africa? We particularly consider changes in species net primary productivity, biomass and distribution, important for evaluating the services provided by plants in the future. With the CARAIB DVM [45-51], we focus on 12 species which are keystone plants for the ecosystem and for people as goods and services. To take the range of possibilities the future may hold into account, we used several climate projections produced by climate models of the Coupled Model Intercomparison Project-Phase 5 (CMIP5; [52]) to 2100 time horizon under two Representative Concentration Pathways, RCP4.5 and RCP8.5 [53].

\section{Materials and Methods}

\subsection{Studied Species}

Equatorial Africa is dominated by tropical rainforests with broadleaved evergreen or raingreen trees, the deciduous character of the forest increasing with the distance from the equator. A total of 12 tree and palm species were selected according to their great importance for local communities in central Africa, especially for the populations of the WWF (World Wide Fund for Nature) Lake Tele-Lake Tumba Landscape (RD Congo), the largest area of swamp and flooded forest in Africa situated at the lowest latitude zone of the Congo Basin (Table 1; species spatial distributions in Supplementary S1). The uses of their ecosystem services have recently been investigated in this region by the multidisciplinary BIOSERF (Sustainability of tropical forest biodiversity and services under climate and human pressure) project [54]. The selection criteria were: a relatively good knowledge of the species distribution (climatic envelop), the number of species-specific morpho-physiological traits available and the quantity and quality of available data on provisioning ecosystem services, covering a wide range of services. Species occurrences were derived from the RAINBIO (African RAIN forest community dynamics: implications for tropical BIOdiversity conservation and climate change mitigation) database [55], compiling distribution data on tropical African plants (e.g., the occurrences available via the Global Biodiversity Information Facility portal, GBIF) and from Fayolle et al. [56]. The species morpho-physiological trait data used in this study mainly come from the TRY database [57] and from the COBIMFO (Congo Basin integrated monitoring for Forest carbon mitigation and biodiversity) project $[58,59]$ (Table 2). Since they are very diverse across the African continent, the selected ES should be interpreted as potential services. It is consistent with the recommendations of Kumar [60] to distinguish between the ability of an ecosystem to provide a service and the actual use of that service. Some of these services have international economic value, such as the palm oil of Elaeis guineensis and the timber of Lophira alata and Pericopsis elata, but most of them are only appraised at local level. We added three functional types of grasses to represent the lower strata in our model, including herbaceous C3 (wet and dry) and C4 types.

\subsection{Climate Data and Future Scenarios}

The climate database of the Climatic Research Unit (CRU; [61]) was used as reference for historical climate conditions. For future climate, the outputs of 33 general circulation models (GCMs) were acquired from the Coupled Model Intercomparison Project Phase 5 (CMIP5) database [52] of the Intergovernmental Panel on Climate Change (IPCC). We analyzed the capacity of those models to reproduce the annual and seasonal climate over Africa in terms of mean, interannual variability and trend of temperature and precipitation over the reference 1980-1999 period by comparing them to 
the CRU data [50]. We selected the five most performing models, here presented by decreasing rank: CNRM-CM5 [62], MPI-ESM-LR [63], CESM1-BGC [64], CanESM2 [65] and MPI-ESM-MR [63] (see Supplementary S2). This list of five models was completed by four GCMs producing extreme results in terms of future minimum and maximum precipitation and temperature changes in order to illustrate the range of potential climate change (see Supplementary S3). As such, we obtained under the RCP 8.5 scenario: CSIRO-Mk3.6.0 [66] for the largest reduction in precipitation (ranked 22nd); CESM1-BGC for the largest increase in precipitation (already among the five best GCMs); CanESM2 for the largest temperature rise (already among the five best GCMs) and INMCM4 [67] for the lowest temperature rise (as all increase; ranked 25th). For each GCM, climatic anomalies between any given year and the reference 1980-1999 period were statistically downscaled to a $0.5^{\circ}$ spatial resolution with a $2 \mathrm{D}$ linear interpolation and then combined to $0.5^{\circ} \mathrm{CRU}$ data for the reference period, using a procedure similar to that proposed by François et al. [46].

Table 1. The selected species and the ecosystem services they provide as reported by the BIOSERF (Sustainability of tropical forest biodiversity and services under climate and human pressure) project [54] supplemented with data from the PROTA (Plant Resources of Tropical Africa) database (www.prota4u.org). The services are food, fodder, medicinal uses (med), ritual or social uses (rit/soc), environmental uses (envi), poison, construction (constr), materials (mat) and fuel.

\begin{tabular}{|c|c|c|c|c|c|c|c|c|c|c|}
\hline \multirow{2}{*}{\multicolumn{2}{|c|}{ Species (Family) }} & \multicolumn{9}{|c|}{ Ecosystem Services } \\
\hline & & food & fodder & med & rit/soc & envi & poison & constr & mat & fuel \\
\hline 1 & Ceiba pentandra (Malvaceae) & $x$ & $x$ & $\mathrm{x}$ & & $\mathrm{x}$ & & $x$ & $\mathrm{x}$ & \\
\hline 2 & Cola acuminata (Malvaceae) & $\mathrm{x}$ & & $\mathrm{x}$ & & & $\mathrm{x}$ & & $\mathrm{x}$ & \\
\hline 3 & Elaeis guineensis (Arecaceae) & $x$ & $x$ & $x$ & & $x$ & & & $x$ & $x$ \\
\hline 4 & Guibourtia demeusei (Fabaceae) & $\mathrm{x}$ & & $\mathrm{x}$ & $x$ & $x$ & $x$ & $x$ & $\mathrm{x}$ & $\mathrm{x}$ \\
\hline 5 & Lophira alata (Ochnaceae) & & & $\mathrm{x}$ & & $\mathrm{x}$ & & $\mathrm{x}$ & $\mathrm{x}$ & $\mathrm{x}$ \\
\hline 6 & Musanga cecropioides (Urticaceae) & $\mathrm{x}$ & & $\mathrm{x}$ & $\mathrm{x}$ & & & $\mathrm{x}$ & $\mathrm{x}$ & \\
\hline 7 & Nauclea diderrichii (Rubiaceae) & & $\mathrm{x}$ & $\mathrm{x}$ & $\mathrm{x}$ & $x$ & & $x$ & $\mathrm{x}$ & $\mathrm{x}$ \\
\hline 8 & Pericopsis elata (Fabaceae) & & & $\mathrm{x}$ & & & & $\mathrm{x}$ & $\mathrm{x}$ & \\
\hline 9 & Pterocarpus soyauxii (Fabaceae) & & & $\mathrm{x}$ & $\mathrm{x}$ & & & $\mathrm{x}$ & $\mathrm{x}$ & $\mathrm{x}$ \\
\hline 10 & Pycnanthus angolensis (Myristicaceae) & & & $\mathrm{x}$ & & $\mathrm{x}$ & $\mathrm{x}$ & $\mathrm{x}$ & $\mathrm{x}$ & $\mathrm{x}$ \\
\hline 11 & Symphonia globulifera (Clusiaceae) & & & $\mathrm{x}$ & & $\mathrm{x}$ & & $\mathrm{x}$ & $\mathrm{x}$ & $\mathrm{x}$ \\
\hline 12 & Uapaca guineensis (Euphorbiaceae) & $\mathrm{x}$ & & $\mathrm{x}$ & & $\mathrm{x}$ & & $\mathrm{x}$ & $\mathrm{x}$ & $\mathrm{x}$ \\
\hline
\end{tabular}

To account for the range of possibilities the future may hold, these climate models operated under four different scenarios of greenhouse gas forcing [53] established by the IPCC. Here, we excluded the unlikely strong mitigation scenario (RCP2.6) and concentrated on more extreme scenarios: RCP4.5 (538 ppmv of $\mathrm{CO}_{2}$ in 2100) and RCP8.5 (936 ppmv of $\mathrm{CO}_{2}$ in 2100), respectively representing stabilization without overshoot and rise of external forcing.

\subsection{The CARAIB Dynamic Vegetation Model}

CARAIB (CARBon Assimilation in the Biosphere) is a process-based model originally developed to understand the role of vegetation in the global carbon cycle $[68,69]$. It has also been used to reconstruct potential vegetation distribution under past climates (e.g., [46,70]) and to project land ecosystem evolution in the future [47], including in tropical regions [49,50]. It calculates the carbon and water transfers between the atmosphere, the vegetation and the soil. Depending on the studied area, vegetation is represented by plant functional types (PFTs) or by a set of selected species that are ecologically or economically important. Each species corresponds to a pool of carbon biomass (wood, leaves) per unit area calculated on every grid cell of the simulated domain. It is not an individual-based model. More detailed descriptions of CARAIB modules can be found in previous studies [47,48,71,72]. Raghunathan et al. $[49,50]$ showed evidence of the rather good accuracy of the model to simulate distribution of species in the tropical Brazilian Atlantic Forest.

The environmental inputs of the model are climate data first: the monthly fields of the mean surface air temperature, diurnal temperature range, precipitation, wind speed, relative sunshine 
hours and air relative humidity; the daily values being determined by a stochastic generator [73]. Other environmental input data include soil characteristics, such as texture and color, the average altitude of the grid cell, and the atmospheric $\mathrm{CO}_{2}$ mixing ratio (which is assumed to be constant on the simulated domain, but varies from year to year).

The outputs of the model are, among others, carbon fluxes and stocks, soil hydrology and surface energy balance. Those of main interest for this study focusing on provisioning services by plants are the calculation of species net primary productivity (NPP expressed per unit area, $\mathrm{g} \mathrm{C} \mathrm{m}^{-2} \mathrm{yr}^{-1}$ ) and species biomass $\left(\mathrm{g} \mathrm{C} \mathrm{m}^{-2}\right)$ by taking interspecific competition for space, light and water into account $[47,71]$. Besides the impacts of temperature, precipitation or sunshine on plant productivity that are easy to infer, relative humidity and wind speed influence respectively the stomatal regulation and the aerodynamics at the top of the canopy. If air relative humidity is low, the plant will tend to close its stomata to prevent water loss. The stronger the wind, the lower aerodynamic resistance and this allows more efficient carbon and water transfers between soil/plant and atmosphere. Increases in evapotranspiration will tend to decrease soil water and thus plant NPP while increased carbon fluxes will tend to increase NPP.

The model also needs input parameters characterizing the simulated plant species. Whereas previous studies used morpho-physiological traits of plant functional types (PFT; [72]), we looked for characteristics of individual species in an attempt to refine the simulations (Table 2). However, plant trait data available for African species remain scarce as already pointed out by Feeley and Silman [44]. In absence of specific traits, PFT parameters are kept [70]. The selected species belong to two different PFTs: broadleaved raingreen tropical trees and broadleaved evergreen tropical trees. The best-characterized parameters at the species level are the tree height, the foliage carbon/nitrogen ratio $(\mathrm{C}: \mathrm{N})$ and the specific leaf area (SLA). The C:N and the SLA modulate the $\mathrm{V}_{\mathrm{cmax}}$ according to the parameterization from Walker et al. [74]. C:N also impacts autotrophic respiration. The intraspecific variations (standard deviation) of C:N and SLA inferred from available values are presented in Table 2. They are respectively lower and higher than the interspecific variations $\left(5.4 \mathrm{~g} \mathrm{~g}^{-1}\right.$ for foliage C:N and $0.008 \mathrm{~m}^{2} \mathrm{~g}^{-1} \mathrm{C}$ for SLA). The climatic tolerances (minimum temperature, $\mathrm{T}_{\text {mins }}$, minimum soil water, $\mathrm{SW}_{\text {mins }}$ ) governing mortality under stress conditions and the threshold values (minimum yearly sum of growing degree-days above $5{ }^{\circ} \mathrm{C}$ GDD5 ${ }_{\text {ming, }}$ and, for drought deciduous species, maximum soil water of the driest month, $\mathrm{SW}_{\operatorname{maxg}}$ ) controlling germination are other species-specific parameters (Table 3). They are inferred from prescribed percentiles in their observed climate distribution, according to the method described by Francois et al. [72] and Laurent et al. [75].

Table 2. The selected species and the morpho-physiological traits for which some values were refined. Grey cells are species-specific values while white cells indicate initial plant functional type (PFT) values. The trait variations (standard deviation) for the foliage carbon/nitrogen ratio (C:N) and the specific leaf area (SLA) are given in addition to the mean value when the number of data is large enough. When species-specific trait data were found, the previous PFT values (standard in CARAIB ${ }^{1}$ ) are noted between brackets.

\begin{tabular}{|c|c|c|c|c|c|c|c|}
\hline & Species & $\begin{array}{c}\text { Height } \\
\text { (m) }\end{array}$ & $\begin{array}{l}\text { Root Depth } \\
(\mathrm{mm})\end{array}$ & PFT $^{2}$ & Fabaceae $^{3}$ & $\begin{array}{c}\text { Foliage C:N } \\
\left(\mathrm{g} \mathrm{g}^{-1}\right)\end{array}$ & $\begin{array}{c}\text { SLA } \\
\left(\mathrm{m}^{2} \mathrm{~g}^{-1} \mathrm{C}\right)\end{array}$ \\
\hline 1 & Ceiba pentandra & $\begin{array}{l}55^{4} \\
(20) \\
\end{array}$ & $\begin{array}{c}610^{4,5} \\
(910)\end{array}$ & 1 & 0 & 30 & $\begin{array}{c}0.037 \pm 0.019^{5} \\
(0.020)\end{array}$ \\
\hline 2 & Cola acuminata & $\begin{array}{l}20^{4} \\
(20)\end{array}$ & 910 & $2^{6,7}$ & $0^{6,7}$ & $\begin{array}{c}12^{6,7} \\
(30)\end{array}$ & $\begin{array}{c}0.041^{6,7} \\
(0.030)\end{array}$ \\
\hline 3 & Elaeis guineensis & $\begin{array}{l}25^{4} \\
(20)\end{array}$ & $\begin{array}{l}600^{4} \\
(910)\end{array}$ & 2 & 0 & 30 & 0.030 \\
\hline 4 & Guibourtia demeusei & $\begin{array}{l}35^{4} \\
(20) \\
\end{array}$ & 910 & $2^{6}$ & $1^{6}$ & $\begin{array}{c}21 \pm 0.7^{6} \\
(25)\end{array}$ & $\begin{array}{c}0.027 \pm 0.006^{6} \\
(0.030)\end{array}$ \\
\hline 5 & Lophira alata & $\begin{array}{l}55^{4} \\
(20)\end{array}$ & 1440 & 1 & 0 & 30 & 0.020 \\
\hline
\end{tabular}


Table 2. Cont.

\begin{tabular}{|c|c|c|c|c|c|c|c|}
\hline & Species & $\begin{array}{l}\text { Height } \\
\text { (m) }\end{array}$ & $\begin{array}{l}\text { Root Depth } \\
\text { (mm) }\end{array}$ & PFT $^{2}$ & Fabaceae $^{3}$ & $\begin{array}{l}\text { Foliage C:N } \\
\qquad\left(\mathrm{g} \mathrm{g}^{-1}\right)\end{array}$ & $\begin{array}{c}\text { SLA } \\
\left(\mathrm{m}^{2} \mathrm{~g}^{-1} \mathrm{C}\right)\end{array}$ \\
\hline 6 & Musanga cecropioides & $\begin{array}{c}30^{4,5} \\
(20)\end{array}$ & 910 & $2^{6}$ & $0^{6}$ & $\begin{array}{c}18 \pm 3.6^{6} \\
(30)\end{array}$ & $\begin{array}{c}0.026 \pm 0.009^{5,6} \\
(0.030)\end{array}$ \\
\hline 7 & Nauclea diderrichii & $\begin{array}{l}45^{4} \\
(20)\end{array}$ & 910 & 2 & 0 & 30 & 0.030 \\
\hline 8 & Pericopsis elata & $\begin{array}{l}45^{4} \\
(20)\end{array}$ & 1140 & 1 & 1 & 25 & 0.020 \\
\hline 9 & Pterocarpus soyauxii & $\begin{array}{l}50^{4} \\
(20)\end{array}$ & 910 & $2^{6}$ & $1^{6}$ & $\begin{array}{c}16 \pm 2.8^{6} \\
(25)\end{array}$ & $\begin{array}{c}0.048 \pm 0.020^{6} \\
(0.030)\end{array}$ \\
\hline 10 & Pycnanthus angolensis & $\begin{array}{l}30^{4} \\
(20)\end{array}$ & 910 & $2^{6}$ & $0^{6}$ & $\begin{array}{c}18 \pm 4.5^{6} \\
(30)\end{array}$ & $\begin{array}{c}0.036 \pm 0.011^{5,6} \\
(0.030)\end{array}$ \\
\hline 11 & Symphonia globulifera & $\begin{array}{l}35^{4} \\
(20)\end{array}$ & 910 & $2^{6}$ & $0^{6}$ & $\begin{array}{l}28^{6} \\
(30)\end{array}$ & $\begin{array}{c}0.027 \pm 0.013^{5,6} \\
(0.030)\end{array}$ \\
\hline 12 & Uapaca guineensis & $\begin{array}{l}25^{4} \\
(20)\end{array}$ & 910 & 2 & 0 & 30 & 0.030 \\
\hline
\end{tabular}

${ }^{1}$ Standard PFT values in CARAIB are derived from the following literature: PFT values of root depth from Shenk and Jackson [76]; deciduousness and Fabaceae from PROTA; foliage C:N from McGroddy et al. [77]; height and SLA from Warnant [78] and references therein; species belonging to the Fabaceae family are characterized by lower C:N. ${ }^{2}$ PFT category with (1) broadleaved raingreen tropical trees and (2) broadleaved evergreen tropical trees. ${ }^{3}$ Categorical variable of Fabaceae with (0) no member of the Fabaceae family and (1) member of the Fabaceae family. ${ }^{4}$ Species-specific values from the PROTA database (www.prota4u.org) ${ }^{5}$ Average values from the TRY database [57] and its individual datasets [79-88]. ${ }^{6}$ Values from the COBIMFO project [58,59]. ${ }^{7}$ Values for Cola sp.

Table 3. Species climatic tolerances to stress (minimum temperature, $\mathrm{T}_{\text {mins, }}$ and, minimum soil water, $\mathrm{SW}_{\mathrm{mins}}$ ) and requirements for germination (minimum yearly sum of growing degree-days above $5{ }^{\circ} \mathrm{C}$ GDD5 ${ }_{\text {ming }}$, and, for drought deciduous species, maximum soil water of the driest month, $\left.\mathrm{SW}_{\text {maxg }}\right)$. Soil water thresholds refer to available soil water in relative units, i.e., in terms of the variable $(\mathrm{W}-\mathrm{WP}) /(\mathrm{FC}-\mathrm{WP})$ where W, WP and FC are respectively the soil water content, the wilting point and the field capacity in $\mathrm{mm}$.

\begin{tabular}{cccccc}
\hline & Species & $\mathbf{T}_{\text {mins }}\left({ }^{\circ} \mathbf{C}\right)$ & Sw $_{\text {mins }}$ & GDD5 $_{\text {ming }}\left({ }^{\circ} \mathbf{C}\right.$ Day) & Sw $_{\text {maxg }}$ \\
\hline 1 & Ceiba pentandra & 6.6 & 0.021 & 5519 & 0.667 \\
2 & Cola acuminata & 7.6 & 0.093 & 5437 & - \\
3 & Elaeis guineensis & 6.2 & 0.020 & 5050 & - \\
4 & Guibourtia demeusei & 10.4 & 0.162 & 6808 & - \\
5 & Lophira alata & 6.8 & 0.600 & 5803 & 0.675 \\
6 & Musanga cecropioides & 6.3 & 0.109 & 5408 & - \\
7 & Nauclea diderrichii & 7.0 & 0.095 & 6144 & - \\
8 & Pericopsis elata & 8.7 & 0.600 & 6868 & 1.025 \\
9 & Pterocarpus soyauxii & 11.0 & 0.134 & 6640 & - \\
10 & Pycnanthus angolensis & 7.2 & 0.069 & 5459 & - \\
11 & Symphonia globulifera & 5.2 & 0.069 & 4039 & - \\
12 & Uapaca guineensis & 6.3 & 0.039 & 5653 & - \\
\hline
\end{tabular}

In order to evaluate the simulated current distribution of the studied species (corresponding to the reference 1980-1999 period in our study) and the change in distribution between present and future, it is necessary to determine a threshold below which the species is considered to be absent [50]. We used NPP instead of biomass thresholds, because uncertainty is larger for the second due to its dependence on an additional parameter (i.e., tree mortality rate). In analogy with the ENM method of setting a threshold under which one considers the probability of presence to be too low, we set the presence threshold at $100 \mathrm{~g} \mathrm{C} \mathrm{m}^{-2} \mathrm{yr}^{-1}$ (close to the threshold used in Raghunathan et al. [50]). Anyway, we preliminary observed that varying the presence threshold in the range of $100-200 \mathrm{~g} \mathrm{C} \mathrm{m}^{-2} \mathrm{yr}^{-1}$ had little impact on the simulated species distributions because NPP sharply decreased below these values, once the climatic conditions are no more suitable. We also chose to maintain the same presence threshold for both PFT- and species-specific morpho-physiological parameters for the sake of comparison. 
The model validation was conducted using CARAIB outputs obtained with the CRU historical dataset using both PFT and mean species-specific traits. To inspect the ability of the model to simulate the observed species distribution, the actual observations of individual tree species occurrence were superimposed over the simulated species NPP and we calculated the sensitivity (Se, proportion of presence data points correctly predicted by the model). To quantify the uncertainty linked to intraspecific trait variations, two additional simulations were performed replacing respectively the mean species foliage $\mathrm{C}: \mathrm{N}$ ratio and SLA values by an extreme value (mean \pm standard deviation). The gross primary productivity (GPP) from a PFT-based simulation was compared to data at biome level of Beer et al. [89].

An interesting asset of DVM is the potential to test several assumptions concerning the vegetation response to environmental changes, and specifically the $\mathrm{CO}_{2}$ fertilization effect (as opposed to niche models which lack a direct mechanical connection between the physiology of the species and climate change), known as the increase of leaf photosynthesis with increasing atmospheric $\mathrm{CO}_{2}$ mixing ratio. However, its long-term effect is uncertain given the interference of other processes on plant growth forcing them to reallocate available resources. Given these uncertainties, CARAIB was driven by climate scenarios under three $\mathrm{CO}_{2}$ configurations:

1. A constant atmospheric $\mathrm{CO}_{2}$ mixing ratio of $330 \mathrm{ppmv}$ ([330] configuration) in the hypothesis that there will be no fertilization effect due to nutrient limitation. Maintaining $\mathrm{CO}_{2}$ concentrations constant in the model is indeed the only way to test this hypothesis since nutrient limitation in the model is only induced by the species $\mathrm{C}: \mathrm{N}$ ratio which is a constant input;

2. An increasing atmospheric $\mathrm{CO}_{2}$ mixing ratio ([var] configuration) according to the projections of RCP4.5 and RCP8.5 scenarios which respectively reach 538 ppmv and 936 ppmv in 2100. This, then, is consistent with the hypothesis that there will be a fertilizing effect and no nutrient limitation;

3. An increasing atmospheric $\mathrm{CO}_{2}$ mixing ratio equal to those of the [var] configuration but accompanied by a downregulation of photosynthetic activity ([down] configuration) in an attempt to take the influence of decreasing nitrogen availability on the $\mathrm{CO}_{2}$ fertilizing effect into account. Whereas the maximum carboxylation rate $\left(\mathrm{V}_{\mathrm{cmax}}\right)$ for the first two is calculated as a function of foliage $\mathrm{C} / \mathrm{N}$ and SLA [74], the third $\mathrm{CO}_{2}$ configuration consists of a calibration of the photosynthesis based on empirical values of $\mathrm{V}_{\mathrm{cmax}}$ and maximum rate of electron transport $\left(\mathrm{J}_{\max }\right)$ measured in free-air $\mathrm{CO}_{2}$ enrichment (FACE) experiments following the meta-analysis of Ainsworth and Rogers [90]. These experiments were conducted mostly in temperate ecosystems. Their results are thus not directly transferable to the tropical species studied here. Nonetheless, we used them to construct an intermediate scenario of $\mathrm{CO}_{2}$ fertilization, as a sensitivity test, since such experiments have essentially not been conducted up to now in the tropics [91].

Changes in NPP and biomass projected for the future under each climatic scenario and $\mathrm{CO}_{2}$ configuration were calculated comparing CARAIB outputs averaged over the 2080-2099 period to the reference 1980-1999 values from the respective scenario.

\section{Results}

\subsection{CARAIB Simulations for the Present}

\subsubsection{Refinement of Morpho-Physiological Traits}

Substitution of PFT morpho-physiological traits by species-specific ones has an important impact on species NPP with significant differences $(p<0.01)$ in mean simulated NPP (average over the distribution) for eight species (Figure 1). Both traits linked to water (height, root depth) and carbon (C:N ratio, SLA) uptake were adjusted. When only the tree height is adapted and set higher than the PFT one (Lophira alata, Nauclea diderrichii, Pericopsis elata, Uapaca guineensis), change in species productivity is not significant, except for Lophira alata with a specific height much higher than the 
PFT value of $20 \mathrm{~m}$. Importantly, increase of tree height leads to a decrease of the mean simulated $\mathrm{NPP}$ of at least $50 \mathrm{~g} \mathrm{C} \mathrm{m}^{-2} \mathrm{yr}^{-1}$. Turbulence intensity, increasing with tree height, induces an increase in the evapotranspiration rate, which results in an increase of plant water stress and in a decrease of plant NPP, despite a concomitant strengthened assimilation (see Section 2.3). A reduction of root depth has little effect on plant productivity (Elaies guineensis). The most pronounced mean NPP decrease is observed for Ceiba pentendra whose decrease of $150 \mathrm{~g} \mathrm{C} \mathrm{m}^{-2} \mathrm{yr}^{-1}$ is a result of a much higher height together with a lower root depth and a SLA increase. The most important increases (Cola acuminata, Musanga cecropioides) correspond to a large decrease of foliage C:N when there is a rather limited increase of tree height. The negative impact of increasing SLA is supported by the trait adjustment of Musanga cecropioides and Pycnanthus angolensis. With same slight height increase and big C:N ratio decrease, the NPP increase is less important for Pycnanthus angolensis with a SLA of 0.036 than for Musanga cecropioides with a SLA of 0.026. The large impact of modifying SLA and foliage C:N parameters is a logical consequence of their direct link with autotrophic respiration and $\mathrm{V}_{\mathrm{cmax}}$.

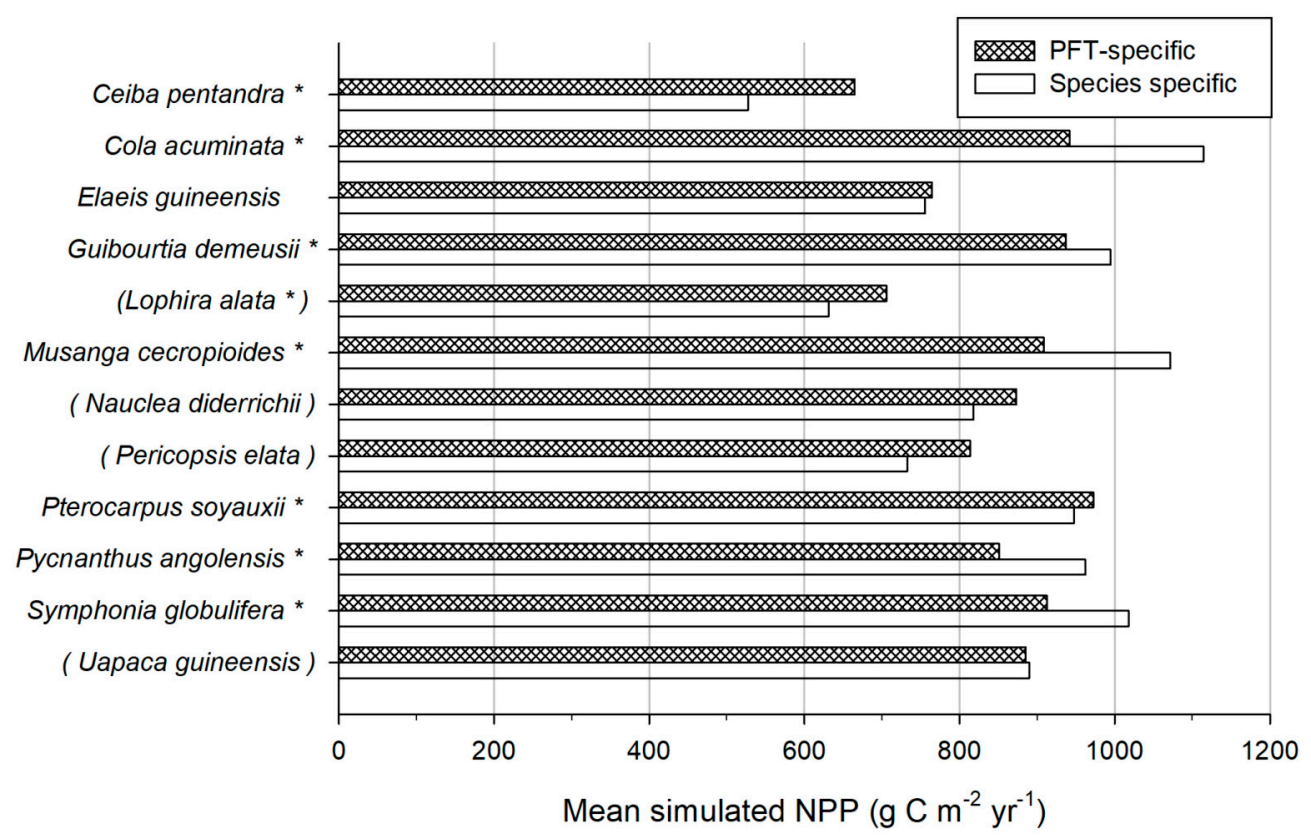

Figure 1. Bar chart of the mean simulated net primary productivity (NPP, $\mathrm{g} \mathrm{C} \mathrm{m}^{-2} \mathrm{yr}^{-1}$ ) over the observed points of species occurrence, obtained with CRU (Climatic Research Unit) historical climatic data for the reference 1980-1999 period, using respectively PFT- (hatched bars) and species-specific (white bars) morpho-physiological traits (see Table 2). An asterisk behind species name indicates a significant difference ( $p$-value of the Wilcoxon paired $t$-test $<0.01$ ) between NPP values. Species name between brackets indicates that only height trait has been adjusted.

Trait adjustment impacts the frequency distribution of NPP values over the species spatial distribution. In the case of Pycnanthus angolensis (Figure 2), the frequency of pixels with a NPP below the threshold of species presence $\left(100 \mathrm{~g} \mathrm{C} \mathrm{m}^{-2} \mathrm{yr}^{-1}\right)$ decreases. Above $100 \mathrm{~g} \mathrm{C} \mathrm{m}^{-2} \mathrm{yr}^{-1}$, the number of grid cells with low NPP values rises consequently but the frequency in high NPP classes also increases. To deepen this analysis, the impact of parameter adjustment on water use efficiency has been examined (Figure 2). It shows that the NPP increase is a direct result of enhanced water use efficiency due to reduced transpiration water loss. However, as already discussed above, trait refinement does not always lead to an increase in species productivity.

To quantify the uncertainty linked to intraspecific trait variations, two additional simulations were performed replacing respectively the mean species foliage C:N ratio and SLA values by an extreme value (mean \pm standard deviation). It results in differences in the mean simulated NPP over the 
observed species occurrences, sometimes significant (up to $90 \mathrm{~g} \mathrm{C} \mathrm{m}^{-2} \mathrm{yr}^{-1}$ for Pycnanthus angolensis with an extreme C:N ratio and up to $170 \mathrm{~g} \mathrm{C} \mathrm{m}^{-2} \mathrm{yr}^{-1}$ for Pterocarpus soyauxii with an extreme SLA).
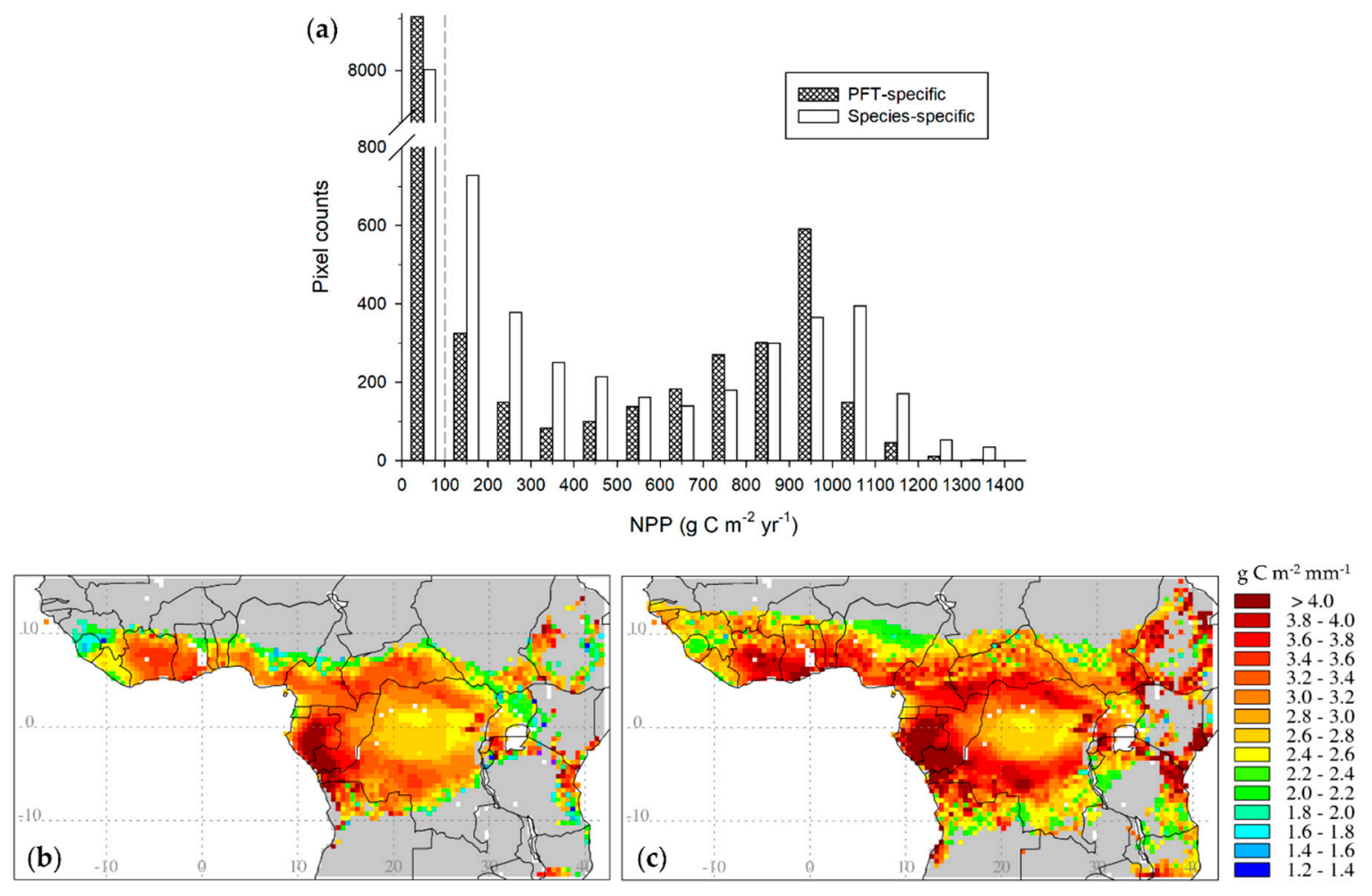

Figure 2. Net primary productivity and water use efficiency of the species Pycnanthus angolensis. (a) Frequency distribution histogram of simulated NPP $\left(\mathrm{g} \mathrm{C} \mathrm{m}^{-2} \mathrm{yr}^{-1}\right)$, using respectively PFT(hatched bars) and species-specific (white bars) morpho-physiological traits (see Table 2). Dotted line indicates the $100 \mathrm{~g} \mathrm{C} \mathrm{m}^{-2} \mathrm{yr}^{-1} \mathrm{NPP}$ threshold. Annual mean water use efficiency $\left(\mathrm{g} \mathrm{C} \mathrm{m}^{-2} \mathrm{~mm}^{-1}\right)$, using (b) PFT- and (c) species-specific traits. Simulations were obtained with CRU historical climatic data for the reference 1980-1999 period.

\subsubsection{Modelling Validation}

The model projects relatively well the distribution of the 12 tree species with sensitivity values higher than 90\% (Table 4), regardless of adjustment of morpho-physiological parameters. Simulated NPP maps with superimposed species occurrences are available for all the species in the Supplementary S1 and the example of Pycnanthus angolensis is given in Figure 3. We note that all the simulated species have a rather similar pattern of distribution. For Pycnanthus angolensis, we observe an extension of the species distribution when species-specific traits are used, encompassing some observed species occurrences (at the northernmost and southernmost latitudes) which were not considered in the species distribution using PFT traits. Yet more importantly, the increase in high NPP values occurs in regions where species presence is attested by observations.

Simulated NPP and biomass values are in the range of the values for tropical trees [92]. According to Whittaker [93], annual NPP varies between $800 \mathrm{~g} \mathrm{C} \mathrm{m}^{-2} \mathrm{yr}^{-1}$ in the tropical seasonal forests and $1100 \mathrm{~g} \mathrm{C} \mathrm{m}^{-2} \mathrm{yr}^{-1}$ in the tropical rain forests. In a seasonal tropical forest of Mexico, wood and root increments are as low as $285 \mathrm{~g} \mathrm{~m}^{-2} \mathrm{yr}^{-1}$ of dry matter, i.e., $143 \mathrm{~g} \mathrm{C} \mathrm{m}^{-2} \mathrm{yr}^{-1}$ [94]. Our GPP results obtained from a PFT-based simulation are also coherent with the ecosystem GPP presented in Beer et al. [89]. For the studied region extended from $16^{\circ} \mathrm{S}$ to $16^{\circ} \mathrm{N}$ in latitude and from $17^{\circ} \mathrm{W}$ to $40^{\circ} \mathrm{E}$ in longitude, the correlation coefficient ( $\mathrm{r}$ ) is equal to 0.92 and the root-mean-square error (RMSE) is equal to $510.89 \mathrm{~g} \mathrm{C} \mathrm{m}^{-2} \mathrm{yr}^{-1}$. Due to the lack of data for the individual species, we were unable to perform an evaluation of productivity at the species level. The fact that the projected species 
distributions do not cover all species occurrences could suggest that the model underestimates NPP values, but it could also be a consequence of the calibration of the germination and stress thresholds for the plant species.

Table 4. Observed species occurrences, species distribution area $\left(10^{6} \mathrm{~km}^{2}\right)$ delimited by the $100 \mathrm{~g} \mathrm{C} \mathrm{m}^{-2} \mathrm{yr}^{-1} \mathrm{NPP}$ threshold and sensitivity (proportion of species occurrences correctly predicted by the model) for both simulations using respectively PFT- and species-specific morpho-physiological traits. Simulations were obtained with CRU historical climatic data for the reference 1980-1999 period.

\begin{tabular}{|c|c|c|c|c|c|c|}
\hline & \multirow{2}{*}{ Species } & \multirow{2}{*}{$\begin{array}{c}\text { Observed } \\
\text { Occurrences } 1\end{array}$} & \multicolumn{2}{|c|}{$\begin{array}{l}\text { Simulation with } \\
\text { PFT-Specific Traits }\end{array}$} & \multicolumn{2}{|c|}{$\begin{array}{c}\text { Simulation with } \\
\text { Species-Specific Traits }\end{array}$} \\
\hline & & & $\begin{array}{l}\text { Distribution Area } \\
\left(10^{6} \mathrm{~km}^{2}\right)\end{array}$ & $\begin{array}{c}\text { Sensitivity } \\
(\%)\end{array}$ & $\begin{array}{l}\text { Distribution Area } \\
\left(10^{6} \mathrm{~km}^{2}\right)\end{array}$ & $\begin{array}{l}\text { Sensitivity } \\
(\%)\end{array}$ \\
\hline 1 & Ceiba pentandra & 197 & 6.59 & 91 & 6.14 & 91 \\
\hline 2 & Cola acuminata & 60 & 6.35 & 98 & 12.76 & 100 \\
\hline 3 & Elaeis guineensis & 118 & 12.87 & 99 & 12.34 & 97 \\
\hline 6 & Musanga cecropioides & 133 & 6.15 & 98 & 7.95 & 99 \\
\hline 7 & Nauclea diderrichii & 126 & 6.12 & 99 & 5.85 & 99 \\
\hline 8 & Pericopsis elata & 40 & 3.93 & 95 & 3.45 & 93 \\
\hline 9 & Pterocarpus soyauxii & 153 & 5.40 & 100 & 8.47 & 99 \\
\hline 10 & Pycnanthus angolensis & 199 & 7.16 & 98 & 10.28 & 100 \\
\hline
\end{tabular}

${ }^{1}$ Number of $0.5^{\circ} \times 0.5^{\circ}$ pixels occupied by the species, using occurrences data [55,56].
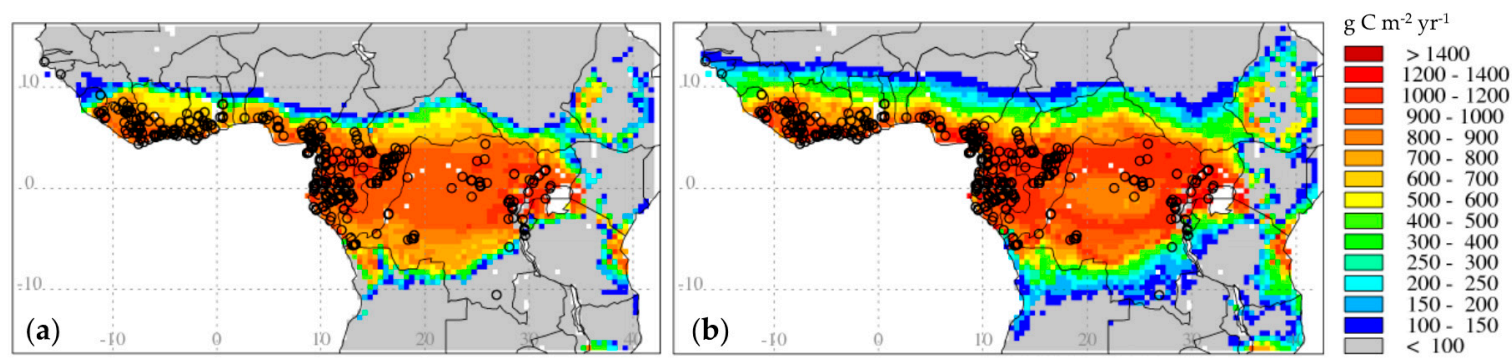

Figure 3. Simulated NPP $\left(\mathrm{g} \mathrm{C} \mathrm{m}^{-2} \mathrm{yr}^{-1}\right)$ for the species Pycnanthus angolensis using (a) PFT- and (b) species-specific traits. The grey color corresponds to simulated NPP values below the $100 \mathrm{~g} \mathrm{C} \mathrm{m}^{-2} \mathrm{yr}^{-1}$ threshold and the black circles to occurrence data $[55,56]$. Simulations were obtained with CRU historical climatic data for the reference 1980-1999 period.

To give a perspective to the model projections for the future, we calculated the change in simulated carbon stock in African tropical forests over historic period for the three $\mathrm{CO}_{2}$ configurations. The biomass change is calculated in terms of annual change between 1968 and 2007 with the idea of a comparison with field plot biomass studies [24]. A biome classification was derived from PFT distributions (same simulation as for GPP validation). Tropical rainforest and tropical deciduous forest (and woodland savanna) biomes were merged to consider entire tropical forests. Biomass change between 1968 and 2007 corresponds to a decrease of $8.1 \mathrm{~g} \mathrm{C} \mathrm{m}^{-2} \mathrm{yr}^{-1}$ under the $\mathrm{CO}_{2}$ [330] configuration, an increase of $48.8 \mathrm{~g} \mathrm{C} \mathrm{m}^{-2} \mathrm{yr}^{-1}$ under the $\mathrm{CO}_{2}$ [var] configuration and an increase of $46.8 \mathrm{~g} \mathrm{C} \mathrm{m}^{-2} \mathrm{yr}^{-1}$ under the $\mathrm{CO}_{2}$ [down] configuration. From long-term plot measurements extrapolated to the continent, Lewis et al. [24] estimated that carbon storage in the biomass of African tropical forests increased by $90.4 \mathrm{~g} \mathrm{C} \mathrm{m}^{-2} \mathrm{yr}^{-1}$ from 1968 to 2007 (95\% confidence interval: $38.7-116.2 \mathrm{~g} \mathrm{C} \mathrm{m}^{-2} \mathrm{yr}^{-1}$ ). CARAIB simulated changes are lower but the trends of both configurations including a fertilization effect fall in the confidence interval of Lewis et al. [24]. 


\subsection{CARAIB Simulations for the Future}

\subsubsection{Climate Scenarios}

For central Africa, the climate models project under the RCP8.5 scenario a rise between $3{ }^{\circ} \mathrm{C}$ (INMCM4) and $7^{\circ} \mathrm{C}$ (CanESM2) of the annual mean temperature between 2080-2099 and 1980-1999 periods. The CNRM-CM5 model, reproducing at best historical climate conditions, projects a rise of maximum $4{ }^{\circ} \mathrm{C}$. For precipitation, the general trend is far less clear, with differences varying between $-40 \%$ (CSIRO-Mk-3.6.0) and +50\% (CESM1-BGC). The CNRM-CM5 model projects an increased rainfall for most grid cells up to $+20 \%$, whereas the other models project reduced rainfall in West Africa and an increase in East Africa. Under the RCP4.5 scenario, the same GCM trends are observed though they are limited to only half of the magnitude observed under the RCP8.5 scenario (temperature and precipitation anomalies for all the GCMs and both RCP scenarios in Supplementary S3).

\subsubsection{Changes in Soil Water Content}

Future soil water availability simulated by CARAIB varies considerably with the climate scenario (Figure 4) and RCP scenario (Figure 5). Where, with the GCM ensemble mean, the vegetation model simulates important decreases of soil water levels with respect to the reference period (Figure 5), it projects rather minor changes with the best-ranked model (CNRM-CM5, Figure 4). Under the scenario projecting the largest precipitation reduction (CSIRO-Mk3.6.0), the model simulates significant soil water reduction in most areas. In case of the largest precipitation increase (CESM1-BGC model), soil water slightly increases in large parts of tropical Africa. Changes in soil water availability are most contrasted for the model projecting largest temperature increase (CanESM2). The GCM ensemble mean clearly shows the difference in soil water induced by RCP scenarios (Figure 5): when considering a rise of external forcing (RCP8.5), soil water decreases with a mean factor of 0.80 , while that decrease is limited to 0.90 when considering a stabilization without overshoot (RCP4.5).
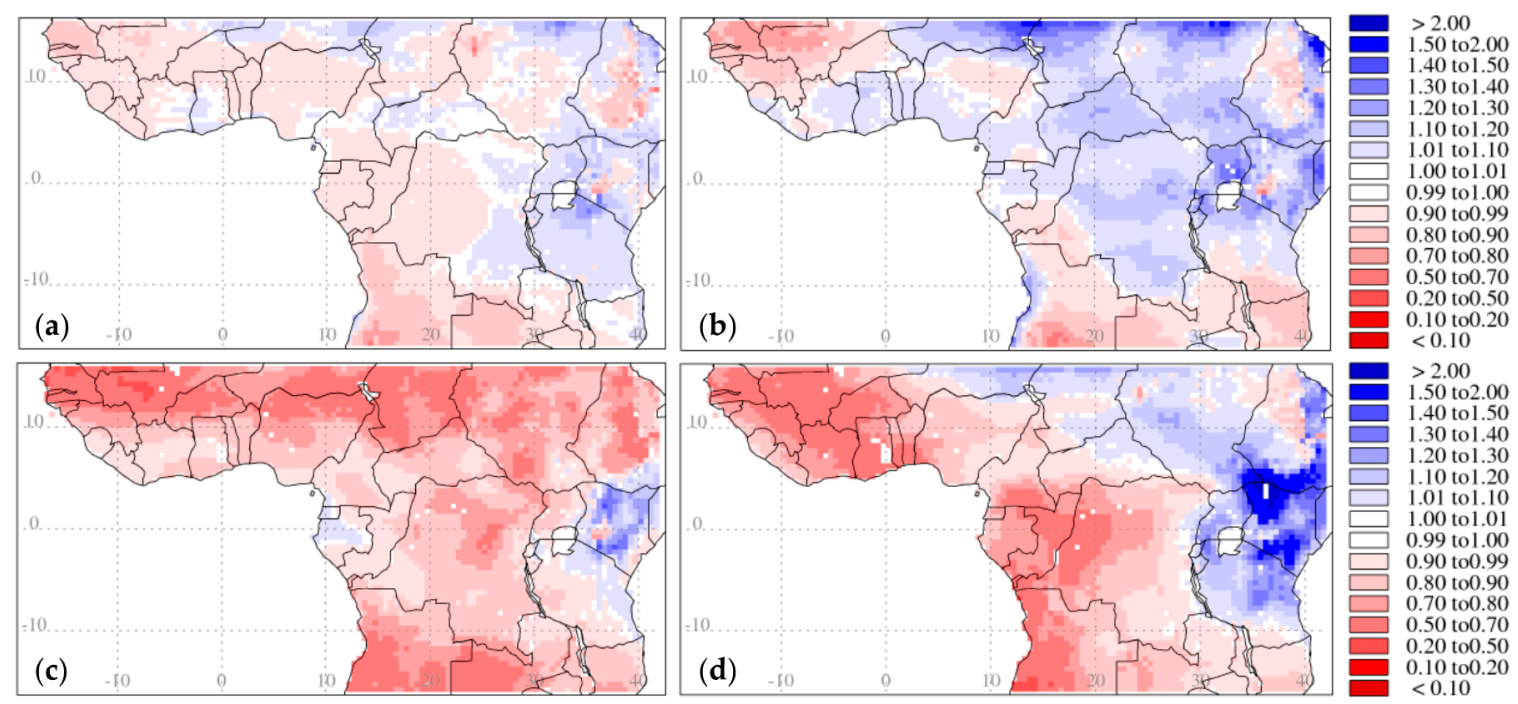

2.00 1.50 to 2.00 1.40 tol.50 .30 to 1.40 .20 to 1.30 1.10 to 1.20 1.01 to 1.10
1.00 to 1.01
0.99 tol.00 0.99 tol. .00 80 to0.99 80 to 0.90
.70 to 0.80 50 to 0.70 20 to0..50 .10 to0.20 $<0.10$

Figure 4. Increase factor of soil water (i.e., the ratio of average available soil water amounts between the annual average over the 2080-2099 period and the reference 1980-1999 period), under the RCP8.5 scenario and a variable $\mathrm{CO}_{2}$ mixing ratio $\left(\mathrm{CO}_{2}\right.$ [var] configuration), for (a) the best ranked model CNRM-CM5, (b) the most humid model CESM1-BGC, (c) the driest model CSIRO-Mk3.6.0, and (d) the warmest model CanESM2. 


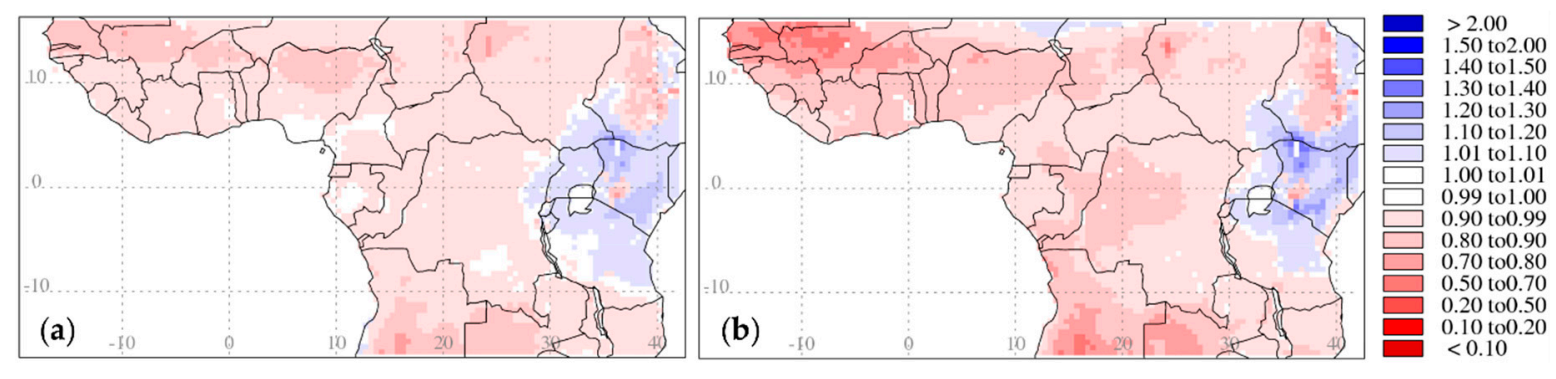

Figure 5. Increase factor of soil water (i.e., the ratio of average available soil water amounts between the annual average over the 2080-2099 period and the reference 1980-1999 period). The values correspond to the ensemble mean of the results obtained with the seven climate projections under (a) the RCP4.5 and (b) the RCP8.5 scenarios, and a variable $\mathrm{CO}_{2}$ mixing ratio $\left(\mathrm{CO}_{2}\right.$ [var] configuration).

\subsubsection{Changes in Productivity and Distribution}

The projected species productivity and distribution are unsurprisingly dependent on the choice of the scenario for future climate, $\mathrm{CO}_{2}$ atmospheric concentrations and potential $\mathrm{CO}_{2}$ fertilization. Change in species distribution is derived from change in NPP between the end of the century (2080-2099) and the reference period (1980-1999). On a grid cell, a species disappears when its NPP goes down below the $100 \mathrm{~g} \mathrm{C} \mathrm{m}^{-2} \mathrm{yr}^{-1}$ presence limit and appears when it outreaches this threshold.

The impacts of the $\mathrm{CO}_{2}$ atmospheric concentrations through RCP4.5 and RCP8.5 climate scenarios and of the $\mathrm{CO}_{2}$ configuration prescribing the species response to increasing $\mathrm{CO}_{2}$ were first analyzed averaging the vegetation model results obtained with the different climate model projections (Figure 6). The RCP8.5 scenario with a constant [330] (no $\mathrm{CO}_{2}$ fertilization effect) is the most pessimistic scenario for the loss of species range. Considering the species ensemble, the model projects a range contraction of $23.6 \%$ but the species may lose up to $30 \%$ of their current distribution (Musanga cecropioides). Assuming a $\mathrm{CO}_{2}$ fertilization effect, the contraction remains under $5 \%$ of the current distribution. Regarding the expansion of species beyond their current distribution (assuming no dispersal limitation), the scenario assuming a $\mathrm{CO}_{2}$ fertilization under RCP8.5 is the most optimistic (expansion of $55.6 \%$ considering the species ensemble). Expansion is at least $20 \%$ (up to $85 \%$ for Guibourtia demeusei) while it does not exceed $15 \%$ under a constant [330]. Reduction and extension of distribution are both less important under RCP4.5 (about the half). The simulations with a variable $\mathrm{CO}_{2}$ mixing ratio but a downregulation of photosynthetic activity do not perform as expected, as the difference with simulations with a variable $\mathrm{CO}_{2}$ mixing ratio and no downregulation is very limited. The differences lie in slightly lower projected expansion beyond the current distribution in the configuration with $\mathrm{CO}_{2}$ downregulation: on average, species range may "only" increase by $28.1 \%$ and $50.4 \%$ under [down] RCP 8.5 and RCP4.5 scenarios against $31.3 \%$ and $55.6 \%$ under [var] scenarios. If we consider the species average, the differences in the projected area expansion are $46.8 \%$ between the [330] and [var] RCP8.5 scenarios, $24.7 \%$ between the [330] and [var] RCP4.5 scenarios, 2.2\% between the [330] RCP4.5 and RCP8.5 scenarios, and 24.3\% between the [var] RCP4.5 and RCP8.5 scenarios. For area contraction, the differences between previous scenarios, respectively $22.6 \%, 11.5 \%, 11.1 \%$ and $0.5 \%$, are less large. This suggests that the uncertainty in potential future distribution linked to plant response to $\mathrm{CO}_{2}$ is, for most of the species, larger than the one related to the representative concentration pathway (considering here only two RCPs).

The divergence in future species distribution due to climate model differences is also important. The projections of area contraction and/or expansion obtained with the different climates are presented in Supplementary S4. The highest inter-model disparity is met with the RCP8.5 scenario. The largest area reductions occur likely under the [330] RCP8.5: 47.8\% of its current distribution for Lophira alata (CanESM2), $46.6 \%$ for Pericopsis elata (CanESM2), and 44.6\% for Musanga cecropioides (MPI-ESM-LR), the first two being deciduous species. But, the [330] RCP8.5 scenario also presents the highest uncertainty. We observe a mean difference of $29.4 \%$ in the lost fraction (average for the 12 species) between extreme climatic scenarios. For instance, there is a difference of $43.2 \%$ in the lost area of Lophira alata under CanESM2 (47.8\% lost) and CNRM-CM5 (only 4.6\% lost). If under some scenarios (even with 
no fertilization effect), the vegetation model projects no contraction of the species distribution, it always projects an area expansion of at least 1.7\% (i.e., Ceiba pentandra under MPI-ESM-LR RCP4.5 and no fertilization scenario). With some climate projections under the [var] RCP8.5, the vegetation model doubles the species area (Guibourtia demeusei under CESM1-BGC or Nauclea diderrichii under CNRM-CM5). But, the difference between projected minimum and maximum area expansion is $41.8 \%$ (average over species), reaching $60.9 \%$ for Nauclea diderrichii (with a minimum area expansion of $47.8 \%$ under MPI-ESM-LR).

(a)

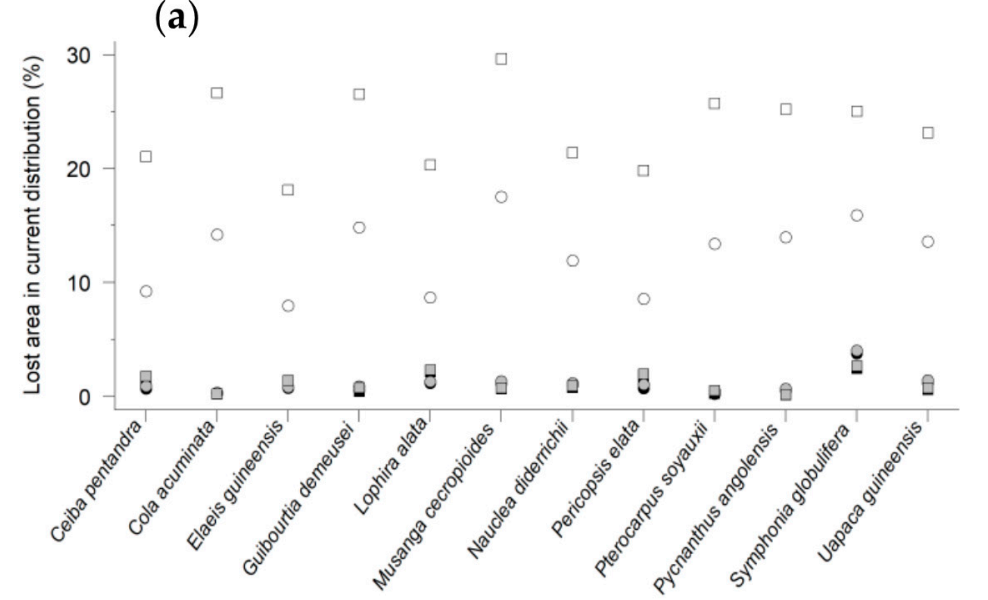

$\mathrm{RCP} 4.5,330 \mathrm{ppmv} \mathrm{CO}_{2}$

$\mathrm{RCP} 8.5,330 \mathrm{ppmv} \mathrm{CO}_{2}$

RCP4.5, downregulated $\left[\mathrm{CO}_{2}\right]$

RCP8.5, downregulated $\left[\mathrm{CO}_{2}\right]$

- RCP4.5, variable $\left[\mathrm{CO}_{2}\right]$

- RCP8.5, variable $\left[\mathrm{CO}_{2}\right]$

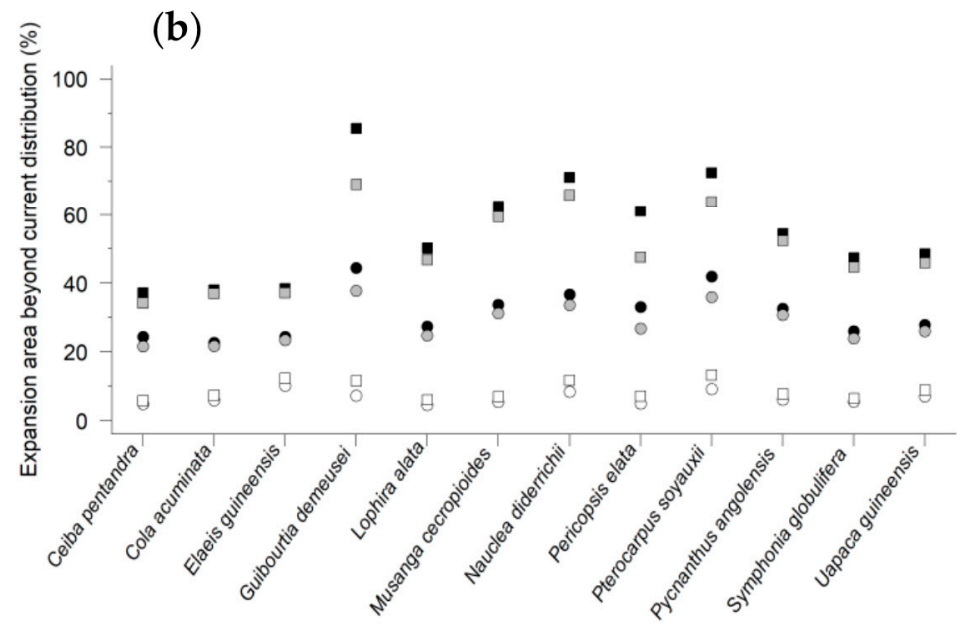

Figure 6. Changes in species distribution between the 2080-2099 period and the reference 1980-1999 period. (a) Lost area in the species current distribution and (b) expansion area beyond the current distribution, considering NPP values above the presence threshold of $100 \mathrm{~g} \mathrm{C} \mathrm{m}^{-2} \mathrm{yr}^{-1}$. The values correspond to the ensemble mean of the results obtained with the seven climate projections under the RCP4.5 (squares) and RCP8.5 (circles) scenarios, and three $\mathrm{CO}_{2}$ configurations assuming respectively a $\mathrm{CO}_{2}$ constant [330] (white), a $\mathrm{CO}_{2}$ variable downregulated [down] (grey) and a $\mathrm{CO}_{2}$ variable [var] (black), and species-specific morpho-physiological traits.

For almost all the $\mathrm{CO}_{2}$ scenarios and species, it is with the CNRM-CM5 (the best ranked model) and CESM1-BGC (largest increase in precipitation) scenarios that current species range is the best preserved (and even expanded) while it is with the CanESM2 (largest temperature rise) and MPI-ESM-LR (2nd ranked model) that the species are projected to be the most endangered. 


\subsubsection{Changes in Biomass}

The future expansion of the species beyond their current distribution being hypothetical due to dispersal limitation, we restricted our assessment of change in biomass stock to current distribution. Our results display the uncertainty in the evolution of the tropical forest biomass linked to plant response to $\mathrm{CO}_{2}$ (Figures 7 and 8). In absence of $\mathrm{CO}_{2}$ fertilization, the species mean biomass is projected to decrease, whatever the climatic scenario (Supplementary S4). If we consider the climate model ensemble (Figure 7), the biomass change projected for the end of the century is significant for all the species. On average, species might lose $21.2 \%$ and $34.5 \%$ in biomass under RCP4.5 and RCP.8.5, with at least $-17 \%$ (Elaeis guineensis) under RCP4.5 to $-46 \%$ (Lophira alata) and $-47 \%$ (Pericopsis elata) under RCP8.5. For these latter two species, biomass reductions even reach respectively $-76 \%$ and $-79 \%$ under RCP8.5 CanESM2 scenario but are less dramatic (only $-11 \%$ ) under RCP4.5 CESM1-BGC and CNRM-CM5 (Supplementary S4). Assuming a $\mathrm{CO}_{2}$ fertilization effect, biomasses of the species ensemble increase by $10.1 \%$ and $12.2 \%$ under RCP4.5 and RCP8.5 (up to $28 \%$ for Elaeis guineensis with the climate ensemble and more than 40\% with RCP8.5 INMCM4). The exceptions are Guibourtia demeusei and Pericopsis elata whose biomass remains unchanged or slightly decreases in the $\mathrm{CO}_{2}$ configuration including a downregulation. It is important to note that, despite the $\mathrm{CO}_{2}$ stimulation of growth, biomass drops (more than 40\% with RCP 8.5 CanESM2 and 20\% with RCP4.5 MPI-ESM-LR) are still projected if we look at individual climatic scenarios. The analysis of the species biomass changes over time (Figure 8) shows that, despite a $\mathrm{CO}_{2}$ stimulation, the biomass of most species might stop increasing or even decrease after 2070, especially under RCP8.5 scenario. Under this scenario, the model projects very contrasted biomass changes between the species (as already noticed in Figure 7).

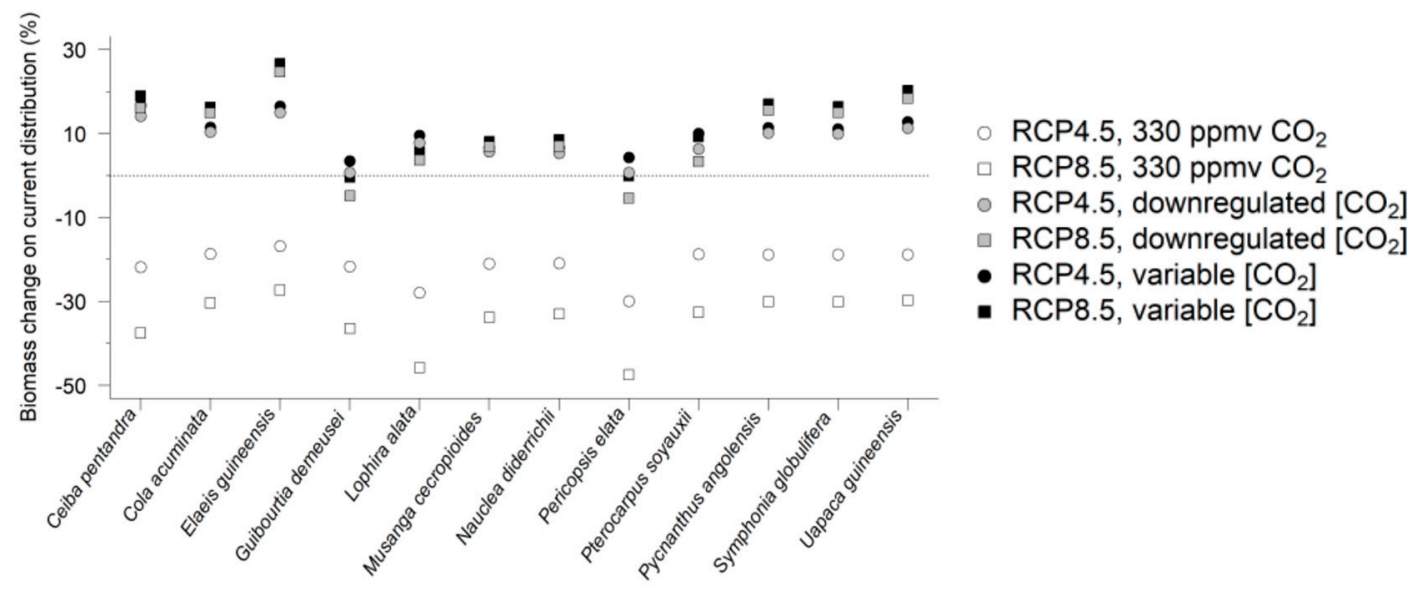

Figure 7. Species biomass change on current distribution between the 2080-2099 period and the reference 1980-1999 period. The values correspond to the ensemble mean of the results obtained with the seven climate projections under the RCP4.5 (squares) and RCP8.5 (circles) scenarios, and three $\mathrm{CO}_{2}$ configurations assuming respectively a $\mathrm{CO}_{2}$ constant [330] (white), a $\mathrm{CO}_{2}$ variable downregulated [down] (grey) and a $\mathrm{CO}_{2}$ variable [var] (black), and species-specific morpho-physiological traits. 

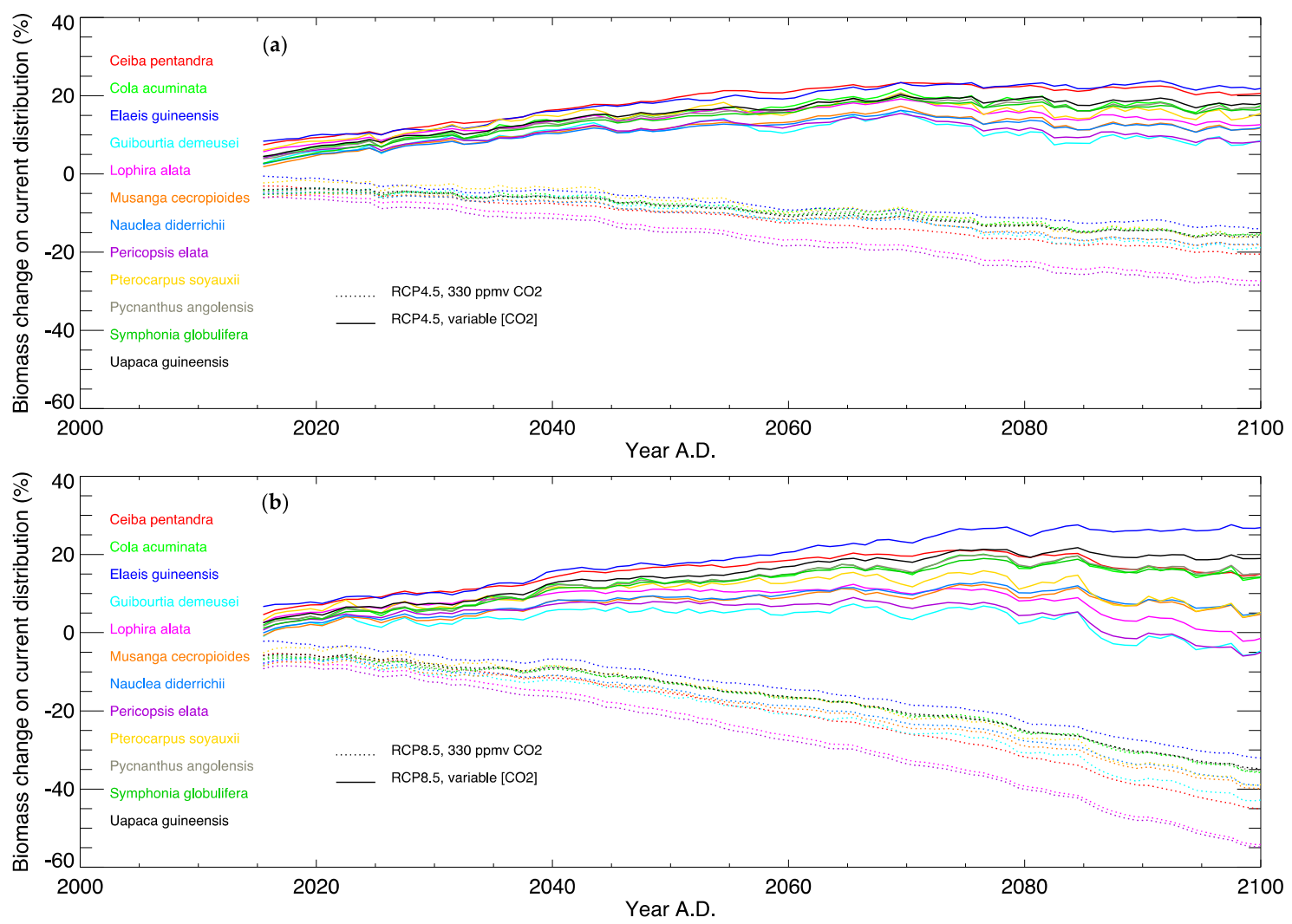

Figure 8. Species biomass change on current distribution over time (from 2015 to 2100) compared to mean biomass for the reference 1980-1999 period. The values correspond to the ensemble mean of the results obtained with the seven climate projections under (a) the RCP4.5 and (b) RCP8.5 scenarios, and two $\mathrm{CO}_{2}$ configurations assuming respectively a $\mathrm{CO}_{2}$ constant [330] (dotted line) and a $\mathrm{CO}_{2}$ variable [var] (solid line), and species-specific morpho-physiological traits.

We also examined the spatial distribution of species biomass changes (examples in Figure 9, maps of all species in Supplementary S5). Changes projected for the 2080-2099 period are evaluated in the light of the temporal variability (standard deviation, $\sigma$ ) of species biomass over the 1980-1999 period. The magnitude of change is expressed as a multiple of the mean biomass standard deviation (average $\sigma$ over the species distribution; [48]). Unsurprisingly, contraction and expansion of species range go together respectively with biomass collapse (especially for Ceiba pentendra, Lophira alata and Pericopsis elata) and gain. Species disappearance is only projected on the distribution edges. Expansions appear in the mountainous areas in East Africa, around the African Great Lakes and the Ethiopian mountains, where climate conditions become suitable for germination. In absence of fertilization effect, our results show that climatic change might lead to an important forest dieback for most species, even in the preserved part of their distribution, with decrease in biomass two to three times the standard deviation for the reference period. When assuming the existence of a fertilization effect, species biomass substantially increases over most of the current distribution. Some biomass declines are however projected at the outer limits as well as in the core of the distribution. 

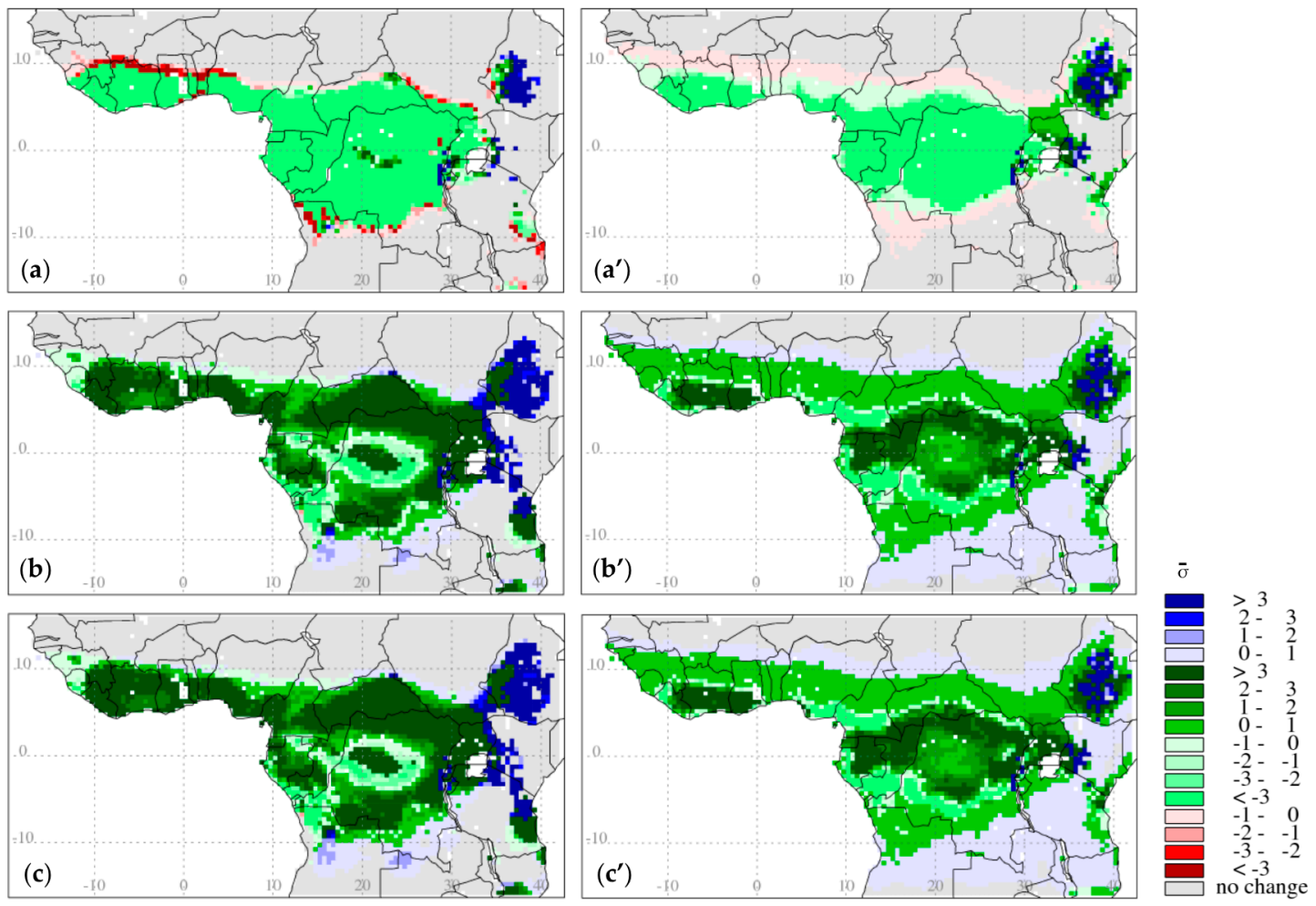

Figure 9. Changes in biomass per unit area $\left(\mathrm{g} \mathrm{C} \mathrm{m}^{-2}\right)$ between 2080-2099 and the reference 1980-1999 period. Biomass change for the species Ceiba pentendra. The magnitude of change is expressed as a multiple of the spatial average of the 1980-1999 biomass standard deviation $\bar{\sigma}\left(704 \mathrm{~g} \mathrm{C} \mathrm{m}^{-2}\right.$ ) over the species current distribution area [48]. Biomasses correspond here to the ensemble mean of the results obtained with the seven climate projections under the RCP8.5 scenario and with species-specific morpho-physiological traits. Three different atmospheric $\mathrm{CO}_{2}$ configurations are tested: (a) a $\mathrm{CO}_{2}$ constant [330], (b) a CO 2 variable downregulated [down], and (c) a $\mathrm{CO}_{2}$ variable [var]. Disappearance of species is indicated in red, expansion in blue and preservation in green colors. Biomass increase and decrease over the preserved range are respectively in dark and light greens. $\left(\mathbf{a}^{\prime}, \mathbf{b}^{\prime}, \mathbf{c}^{\prime}\right)$ the same for Musanga cecropioides with a $\bar{\sigma}$ of $828 \mathrm{~g} \mathrm{C} \mathrm{m}^{-2}$. See Supplementary S5 for all the species.

\section{Discussion}

We presented here an analysis of climate change impacts on tropical tree species in central Africa using the CARAIB dynamic vegetation model. For this purpose, we refined species parameterization from PFT- to species-specific traits we could find in morpho-physiological trait databases or collect from previous projects, for 12 species (trees and palms) known to be widely used by local populations in central Africa. Our results clearly show the sensitivity of species productivity to these traits and their intraspecific variations with a direction in NPP change depending on the new combination of traits. For instance, the productivity of Pycnanthus angolensis increases while the one of Ceiba pentandra decreases. This indicates that the trait acclimation does not necessarily results in NPP increase, which is rather in accord with Poorter et al. [95]. They concluded that traits at individual level are poor predictors of growth performances while traits strongly vary within species with environmental conditions. Though we did not introduce the traits separately, the analysis of the 12 species modifications (Table 2) allowed to disentangle the effects of each trait on species physiology. Following the formulation of Walker et al. [74], the maximum carboxylation rate $\left(\mathrm{V}_{\mathrm{cmax}}\right)$ is a function of foliage C:N ratio and specific leaf area (SLA). A decrease of foliage C:N induces both an augmentation of photosynthetic activity and a slighter augmentation of leaf respiration driving at an increased species NPP. A decrease of the specific leaf area corresponds to an increase of the leaf thickness (if leaf density is constant) meaning an increase in the number of chloroplasts. This induces a rise of the 
maximum carboxylation rate $\left(\mathrm{V}_{\mathrm{cmax}}\right)$ but the consequently more important leaf biomass (higher leaf thickness) also causes higher respiration costs. The resulting effect on species productivity is less direct. In humid conditions like in equatorial Africa, a reduced SLA results in improved photosynthetic activity and higher species productivities but, in drier climates, photosynthesis may be limited by stomatal closure.

The vegetation model projects relatively similar distribution patterns for all the species and, despite high sensitivity values, seems to overestimate some of them. A first reason might be an underestimation of actual species ranges, not fully covered by observations. Knowledge of plant species distribution in tropical Africa is improving but it remains limited [55]. However, there are other explanations for these discrepancies. The model projects the potential climatic species distribution ignoring notably past species migration and dispersal that have shaped —and maybe limited-their current pattern [96]. The interspecific competition occurring in the modelling between the 12 studied species (as well as with the herbaceous strata) does not integrate all the aspects of competition between the plants and does not take the other biotic interactions like parasitism and herbivory into account, which might affect species NPP [48]. The rather coarse $0.5^{\circ}$ spatial resolution of the simulations and of the gridded historical climate dataset [61] derived from monthly observations at meteorological stations, still very few in Africa, are other sources of uncertainties. The limited field data [44,97] make also difficult the validation of the simulated productivity and carbon stocks at the species level. We showed that the mean grid cell GPPs simulated by CARAIB are comparable to the observation-based estimate of ecosystem GPP presented in Beer et al. [89]. We also examined the change in carbon storage in biomass projected by CARAIB for recent period (between 1968 and 2007) in the light of the analysis of Lewis et al. [24] based on long-term monitoring plots in intact (no human disturbances like deforestation) African tropical forests. The model simulates an increase in tropical forest biomass as observed in long-term plots but only if plants are assumed to respond positively to increasing atmospheric carbon dioxide concentrations $\left(\mathrm{CO}_{2}\right.$ [var] and [down] configurations). However, the projected increase is clearly less important than reported by Lewis et al. [24], even if it falls in their confidence interval. Thus, our results suggest the existence of a fertilization effect. But, they also imply that the increase of atmospheric $\mathrm{CO}_{2}$ cannot explain alone the increase in forest biomass in recent years. Recovery of long-lived trees from past anthropogenic or natural disturbances, a component difficult to take into account in modelling but also hardly monitored, may be another important explanation for the observed biomass increment. With a remote sensing approach, Liu et al. [98] estimated for 1993-2012 only a slight carbon increase over the intact tropical forests. Combined with a considerable deforestation (not included in our simulations), the net effect corresponds to a decline of $0.01 \mathrm{PgC}_{\mathrm{yr}}^{-1}$ for the African tropical forests and more important decreases of 0.16 and $0.09 \mathrm{PgC}^{-1}$ respectively for

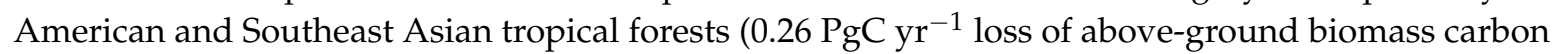
for global tropical forests).

The potential $\mathrm{CO}_{2}$ effect in the long term is however uncertain given the interference of other processes on growth, forcing plants to reallocate available resources. Smith et al. [99] highlighted the current lack of long-term responses of vegetation in models while modelling studies can especially broaden our knowledge of these processes [100]. Among existing models that incorporate dynamic algorithms, there are many differences between these algorithms and between the types of responses considered. Some describe acclimation (mid-term responses, taking days to occur) of respiration to temperature and other acclimations of photosynthetic activity to temperature or atmospheric $\mathrm{CO}_{2}$ mixing ratio. At present, no model integrates these three types of response simultaneously. In this study, we attempted to implement in our model an empirical algorithm based on FACE (Free-air $\mathrm{CO}_{2}$ Enrichment) experimental data [90] to simulate an acclimation of photosynthesis to increased atmospheric $\mathrm{CO}_{2}$ mixing ratio. To date, FACE measurements are the most appropriate data despite their limitations: experiments conducted at the PFT level in temperate or desert zones (without tropical species) with a duration limited to a few years and disputed causal mechanisms [99]. Therefore, our results with a downregulated $\mathrm{CO}_{2}$ response must be considered as a first attempt and interpreted with 
caution (see below). Further research is recommended to implement photosynthesis downregulation in vegetation models, for instance by integration of a kind of optimization provided by the plant when photosynthetic activity tends to increase. Optimizing allocation and utilization of nutrients allow the plant to reach a compromise between the advantage of having a high Rubisco activity and the cost of maintaining it by respiration (e.g., [101]).

In our results, the differences between the climatic scenarios from seven GCMs under two RCPs and three $\mathrm{CO}_{2}$ configurations highlight the large uncertainties in the future of African tropical tree species. They are first related to uncertainties in the climatic scenarios [102]. The GCMs selected for our study vary greatly in their projections of future precipitation although several of them project increases in precipitation in eastern Africa and decreases in western Africa likewise in James et al. [103]. Soil water content anomalies (increasing factor) projected by the model show that the temperature rise emphasizes soil water deficits, even in areas where climatic models project unchanged or increasing rainfall. Projected changes in species distribution vary greatly in function of the GCM climatic anomalies for the 21st century (uncertainties of $29.4 \%$ in the lost fraction and $41.8 \%$ in the area expansion beyond current distribution) and, to a lesser extent, of the concentration pathway, considering only two RCPs (differences of 11.1\% between the [330] RCP4.5 and RCP8.5 scenarios for the area contraction and $24.3 \%$ between the [var] RCP4.5 and RCP8.5 scenarios for the range expansion). The question about long-term plant response to increasing $\mathrm{CO}_{2}$ concentrations also leads to important differences in simulated future distributions. Our simulated range contraction and expansion for the species ensemble vary respectively of $22.6 \%$ and $46.8 \%$ between the [330] and [var] RCP8.5 scenarios. It is confirmed by Rammig et al. [104] in a study evaluating the risk of dieback in the Amazonian forest. The availability of the nutrients also raises questions as in Cusack et al. [27] and Huntingford et al. [105] studies which concluded that the largest uncertainties are associated with physiological and nutrient cycling responses of plants.

In absence of the fertilization effect, in our simulations ( $\mathrm{CO}_{2}$ [330] configuration), species are exposed to climate change and might lose under RCP8.5 25\% (12.5\% under RCP4.5) of their distribution on average (mean value for the ensemble of both species and climatic scenarios). The most vulnerable species seems to be Musanga cecropioides (30\% of lost area) followed by Cola acuminata and Guirboutia demeusei (27\%). Projected range expansions are also too limited to offset range contraction and moreover highly unpredictable. By contrast, if the long-term species response to increasing atmospheric $\left[\mathrm{CO}_{2}\right]$ is positive $\left(\mathrm{CO}_{2}\right.$ [var] configuration), the simulated future expansion might largely compensate for a range reduction limited to $5 \%$. But, as already mentioned, the extent of expansion beyond current distribution is extremely dependent on the scenario, e.g., from $20 \%$ to $85 \%$ for Guibourtia demeusii. The simulations with $\mathrm{CO}_{2}$ [down] configuration exhibit some downregulation, especially apparent in the area expansion less important than projected under $\mathrm{CO}_{2}$ [var] configuration, but the effects of this acclimation are more limited than expected. In these two configurations, the current distribution of the 12 studied species has a good chance to be preserved. These results are consistent with those produced by other mechanistic models for tropical areas (e.g., [106]). According to Lloyd et al. [107], tropical forests are not "dangerously close" to their thermal optimum since the new temperature and atmospheric $\mathrm{CO}_{2}$ mixing ratio conditions may produce higher growth rates [108]. Nevertheless, our findings also highlight that, if species range might be totally or partly preserved, there are large uncertainties on future biomass stocks. In absence of a long-term $\mathrm{CO}_{2}$ fertilization effect, CARAIB projects significant dieback (i.e., amplitude of biomass loss two to three times the biomass variability calculated for the reference period) over all the conserved distribution. Considering the species ensemble, it means an average biomass loss of $-21.2 \%$ under RCP 4.5 and $-34.5 \%$ under RCP8.5. Despite a mean biomass increase of $12.2 \%$, assuming a positive feedback of increasing $\mathrm{CO}_{2}$ does not prevent tree dieback both at the outer limits and in the core of the preserved distributions. This shows the competing effects that climate change and $\mathrm{CO}_{2}$ fertilization might have $[109,110]$.

This zoom on 12 individual species confirms that individual species respond differently to new climatic and atmospheric conditions, which may induce a new dynamics of competition in the 
ecosystem. For example, whereas the model projects under $\mathrm{RCP} 8.5 \mathrm{CO}_{2}$ [var] configuration that mean biomass might increase by as much as $28 \%$ for Elaeis guineensis, it simulates unchanged biomass stock for Guibourtia demeusei and Pericopsis elata. Under RCP8.5 CO $\mathrm{CO}_{2}$ [330] configuration, the three deciduous species (Ceiba pentandra, Lophira alata and Pericopsis elata) of our set are projected to experience the strongest dieback (around 50\% of biomass loss over the current distribution). The impact differs also significantly between smaller study areas. For instance, over the WWF Lake Tele-Lake Tumba Landscape in DR Congo, a forest-savanna mosaic with strong spatial variation in forest biomass [111], the currently present species would not profit off the new conditions; they would sustain but not amplify current production rates. On the contrary, previously (nearly) absent species would appear and amplify their production rates exponentially. Such a species turnover would not be a favorable situation since those species not necessarily have the same role in the ecosystem nor provide the same services. Today, countryside way of life still partly relies on conventional plant uses.

Finally, we want to notice that the traits values used in this study are measured under current climate conditions and that, under influence of climate change, acclimation of these traits may occur. For example, Santiago et al. [112] highlight that rooting depth could be a major determinant of how tropical trees will fare during extreme droughts. Assumptions on the physiological responses of species to new climatic conditions thus remain necessary [49]. These results must also be analyzed keeping in mind the absence of anthropogenic actions and species dispersal/migration limitations. Synergistic interactions and feedbacks of clearing and forest fragmentation certainly have major implications for the vulnerability of forests to climate change. While the precise sensitivity is not known, human activities appear to increase the climate sensitivity of forest areas that are not directly affected by these activities, causing feedbacks on global and regional climates [30,102]. At the same time, Scheiter et al. [113] showed that appropriate ecosystem management can mitigate climate change impacts on vegetation and delay or avoid undesired vegetation shifts. We thus emphasize the potential gain of studies that examine human and climate pressures simultaneously (e.g., [114]). The development of approaches that integrate two spatial and dynamic models, one simulating vegetation and the other simulating land use by human agents (multi-agent model), should be encouraged to expand our knowledge of the complex interactions between human beings and ecosystems. The call for the integration of perspectives of natural sciences with those of social sciences $[115,116]$ is then obvious. The question also arises whether the species would be able to migrate in order to reach newly suitable potential areas. In the WWF Lake Tele-Lake Tumba Landscape, the transport of zoochoric species seeds is clearly limited by hunting [117] and more widespread fires [102]. Other human activities such as slash-and-burn agriculture, road construction or habitat fragmentation may also represent barriers or challenges to migration, though the impact of anthropic actions in determining the ability of plant populations to disperse remains poorly understood [118].

\section{Conclusions}

Our study with the CARAIB dynamic vegetation model shows the specific response of tree species to climate change, urging for impact assessments carried out at the species level in parallel with ecosystem analyses. In Africa more than anywhere else, the lack of observations for species inventory and measurements of morpho-physiological traits limits thus our knowledge of species physiology and distribution. CARAIB results highlight the large uncertainties in the climate projections for the end of the century and in the long-term physiological responses to $\mathrm{CO}_{2}$ concentration increase. The model projects contrasted future species distributions and functioning assuming or not a stimulation of plant growth by $\mathrm{CO}_{2}$, with NPP and biomass decreases (more or less pronounced) regardless of the long-term fertilization hypothesis.

Supplementary Materials: The following are available online at http:/ /www.mdpi.com/1999-4907/9/11/722/s1, Supplementary S1 (Figure): Simulated NPP for the 12 studied species, Supplementary S2 (Table): Information about the selected CMIP5 global climate models, Supplementary S3 (Figures 1 and 2): Annual mean temperature and annual precipitation anomalies between the 2080-2099 period and the reference 1980-1999 period for the 
7 selected GCMs, Supplementary S4 (Figures 1-3): Lost area in the species current distribution, expansion area beyond the current distribution and species biomass change on current distribution between the 2080-2099 period and the reference 1980-1999 period obtained with the seven climate projections, Supplementary S5 (Figure): Changes in biomass per unit area between 2080-2099 and the reference 1980-1999 period for the 12 studied species (the magnitude of change expressed as a multiple of the spatial average of the 1980-1999 biomass standard deviation over the species current distribution area).

Author Contributions: L.F. and A.H. conceived and designed the study; A.F. and H.V. acquired data about respectively observed species occurrences and species-specific morpho-physiological traits; M.D. prepared all the input data of the model; M.D. and L.M. performed the simulations; M.D., L.M., L.F. and A.H. analysed the results, M.D. and L.M. wrote the manuscript; and L.F., A.H., A.F. and H.V provided some core advice, reviewed and edited the paper.

Funding: Funding for this research by the BIOSERF and the AFRIFORD projects within the SSD and BRAIN-be programs of Belgian Science Policy (BELSPO) is gratefully acknowledged.

Acknowledgments: We acknowledge the World Climate Research Programme's Working Group on Coupled Modelling, which is responsible for CMIP, and we thank the climate modeling groups (listed in Supplementary $S$ of this paper) for producing and making available their model outputs. For CMIP the U.S. Department of Energy's Program for Climate Model Diagnosis and Intercomparison provides coordinating support and led development of software infrastructure in partnership with the Global Organization for Earth System Science Portals. The study has been supported by the TRY initiative on plant traits (http:/ / www.try-db.org). The TRY initiative and database is hosted, developed and maintained by J. Kattge and G. Bönisch (Max Planck Institute for Biogeochemistry, Jena, Germany). TRY is currently supported by DIVERSITAS/Future Earth and the German Centre for Integrative Biodiversity Research (iDiv) Halle-Jena-Leipzig. The study equally draws on data from the PROTA database (www.prota4u.org) and COBIMFO project (BELSPO).

Conflicts of Interest: The authors declare no conflict of interest.

\section{References}

1. Brink, A.B.; Eva, H.D. Monitoring 25 years of land cover change dynamics in Africa: A sample based remote sensing approach. Appl. Geogr. 2009, 29, 501-512. [CrossRef]

2. Food and Agriculture Organization of the United Nations (FAO). State of the World's Forests; FAO: Rome, Italy, 2012; p. 56. ISBN 978-9251072929.

3. O'Farrell, P.J.; Anderson, P.M.L.; Le Maitre, D.C.; Holmes, P.M. Insights and opportunities offered by a rapid ecosystem service assessment in promoting a conservation agenda in an urban biodiversity hotspot. Ecol. Soc. 2012, 17, 27. [CrossRef]

4. Grace, J.; San José, J.; Meir, P.; Miranda, H.S.; Montes, R.A. Productivity and carbon fluxes of tropical savannas. J. Biogeogr. 2006, 33, 387-400. [CrossRef]

5. Norris, K.; Asase, A.; Collen, B.; Gockowksi, J.; Mason, J.; Phalan, B.; Wade, A. Biodiversity in a forest-agriculture mosaic-The changing face of West African rainforests. Biol. Conserv. 2010, 143, 2341-2350. [CrossRef]

6. Boko, M.; Niang, I.; Nyong, A.; Vogel, C.; Githeko, A.; Medany, M.; Osman-Elasha, B.; Tabo, R.; Yanda, P. Africa. In Climate Change 2007: Impacts, Adaptation and Vulnerability. Contribution of Working Group II to the Fourth Assessment Report of the Intergovernmental Panel on Climate Change; Parry, M.L., Canziani, O.F., Palutikof, J.P., van der Linden, P.J., Hanson, C.E., Eds.; Cambridge University Press: Cambridge, UK, 2007; pp. 433-467.

7. Brodie, J.; Post, E.; Laurance, W.F. Climate change and tropical biodiversity: A new focus. Trends Ecol. Evol. 2012, 27, 145-150. [CrossRef] [PubMed]

8. Iloweka, E.M. The Deforestation of Rural Areas in the Lower Congo Province. Environ. Monit. Assess. 2004, 99, 245-250. [CrossRef] [PubMed]

9. Ahrends, A.; Burgess, N.D.; Milledge, S.A.H.; Bulling, M.T.; Fisher, B.; Smart, J.C.R.; Clarke, G.P.; Mhoro, B.E.; Lewis, S.L. Predictable waves of sequential forest degradation and biodiversity loss spreading from an African city. Proc. Natl. Acad. Sci. USA 2010, 107, 14556-14561. [CrossRef] [PubMed]

10. Keenan, R.J.; Reams, G.A.; Achard, F.; de Freitas, J.V.; Grainger, A.; Lindquist, E. Dynamics of global forest area: Results from the FAO Global Forest Resources Assessment 2015. For. Ecol. Manag. 2015, 352, 9-20. [CrossRef]

11. Yadav, P.K.; Sarma, K.; Kumar, R. A framework for assessing the impact of urbanization and population pressure on Garo hills landscape of north-east India. Int. J. Conserv. Sci. 2013, 4, 213-222. 
12. Kukkonen, M.; Käyhkö, N. Spatio-temporal analysis of forest changes in contrasting land use regimes of Zanzibar, Tanzania. Appl. Geogr. 2014, 55, 193-202. [CrossRef]

13. Thilagavathi, N.; Subramani, T.; Suresh, M. Land use/land cover change detection analysis in Salem Chalk Hills, South India using remote sensing and GIS. Disaster Adv. 2015, 8, 44-52.

14. Pessoa, M.S.; Rocha-Santos, L.; Talora, D.C.; Faria, D.; Mariano-Neto, E.; Hambuckers, A.; Cazetta, E. Fruit biomass availability along a forest cover gradient. Biotropica 2016, 49, 45-55. [CrossRef]

15. Pütz, S.; Groeneveld, J.; Alves, L.F.; Metzger, J.P.; Huth, A. Fragmentation drives tropical forest fragments to early successional states: A modelling study for Brazilian Atlantic forests. Ecol. Model. 2011, 222, 1986-1997. [CrossRef]

16. Tabarelli, M.; Peres, C.A.; Melo, F.P.L. The 'few winners and many losers' paradigm revisited: Emerging prospects for tropical forest biodiversity. Biol. Conserv. 2012, 155, 136-140. [CrossRef]

17. Niang, I.; Ruppel, O.C.; Abdrabo, M.A.; Essel, A.; Lennard, C.; Padgham, J.; Urquhart, P. Africa. In Climate Change 2014: Impacts, Adaptation, and Vulnerability. Part B: Regional Aspects. Contribution of Working Group II to the Fifth Assessment Report of the Intergovernmental Panel on Climate Change; Barros, V.R., Field, C.B., Dokken, D.J., Mastrandrea, M.D., Mach, K.J., Bilir, T.E., Chatterjee, M., Ebi, K.L., Estrada, Y.O., Genova, R.C., et al., Eds.; Cambridge University Press: Cambridge, UK; New York, NY, USA, 2014; pp. 1199-1265.

18. Gonzalez, P.; Neilson, R.P.; Lenihan, J.M.; Drapek, R.J. Global patterns in the vulnerability of ecosystems to vegetation shifts due to climate change. Glob. Ecol. Biogeogr. 2010, 19, 755-768. [CrossRef]

19. Lewis, S.L.; Sonké, B.; Sunderland, T.; Begne, S.K.; Lopez-Gonzalez, G.; van der Heijden, G.M.F.; Phillips, O.L.; Affum-Baffoe, K.; Baker, T.R.; Banin, L.; et al. Above-ground biomass and structure of 260 African tropical forests. Philos. Trans. R. Soc. B 2013, 368, 20120295. [CrossRef] [PubMed]

20. Malhi, Y.; Adu-Bredu, S.; Asare, R.A.; Lewis, S.L.; Mayaux, P. African rainforests: Past, present and future. Philos. Trans. R. Soc. B 2013, 368, 20120312. [CrossRef] [PubMed]

21. Bunting, E.L.; Fullman, T.; Kiker, G.; Southworth, J. Utilization of the SAVANNA model to analyze future patterns of vegetation cover in Kruger National Park under changing climate. Ecol. Model. 2016, 342, 147-160. [CrossRef]

22. Hély, C.; Bremond, L.; Alleaume, S.; Smith, B.; Sykes, M.T.; Guiot, J. Sensitivity of African biomes to changes in the precipitation regime. Glob. Ecol. Biogeogr. 2006, 15, 258-270. [CrossRef]

23. Williams, C.A.; Hanan, N.P.; Neff, J.C.; Scholes, R.J.; Berry, J.A.; Denning, A.S.; Baker, D.F. Africa and the global carbon cycle. Carbon Balance Manag. 2007, 2, 3. [CrossRef] [PubMed]

24. Lewis, S.L.; Lopez-Gonzalez, G.; Sonké, B.; Affum-Baffoe, K.; Baker, T.R.; Ojo, L.O.; Phillips, O.L.; Reitsma, J.M.; White, L.; Comiskey, J.A.; et al. Increasing carbon storage in intact African tropical forests. Nature 2009, 457, 1003-1007. [CrossRef] [PubMed]

25. Chambers, L.E.; Altwegg, R.; Barbraud, C.; Barnard, P.; Beaumont, L.J.; Crawford, R.J.M.; Durant, J.M.; Hughes, L.; Keatley, M.R.; Low, M.; et al. Phenological Changes in the Southern Hemisphere. PLoS ONE 2013, 8, e75514. [CrossRef] [PubMed]

26. Grace, J.; Mitchard, E.; Gloor, E. Perturbations in the carbon budget of the tropics. Glob. Chang. Biol. 2014, 20, 3238-3255. [CrossRef] [PubMed]

27. Cusack, D.F.; Karpman, J.; Ashdown, D.; Cao, Q.; Ciochina, M.; Halterman, S.; Lydon, S.; Neupane, A. Global change effects on humid tropical forests: Evidence for biogeochemical and biodiversity shifts at an ecosystem scale. Rev. Geophys. 2016, 54, 523-610. [CrossRef]

28. Ludwig, F.; Franssen, W.; Jans, W.; Beyenne, T.; Kruijt, B.; Supit, I. Climate change impacts on the Congo Basin region. In Climate Change Scenarios for the Congo Basin; Report No. 11; Haensler, A., Jacob, D., Kabat, P., Ludwig, F., Eds.; Climate Service Centre: Hamburg, Germany, 2013.

29. Moncrieff, G.R.; Scheiter, S.; Slingsby, J.A.; Higgins, S.I. Understanding global change impacts on South African biomes using Dynamic Vegetation Models. S. Afr. J. Bot. 2015, 101, 16-23. [CrossRef]

30. Erfanian, A.; Wang, G.; Yu, M.; Anyah, R. Multimodel ensemble simulations of present and future climates over West Africa: Impacts of vegetation dynamics. J. Adv. Model. Earth Syst. 2016, 8, 1411-1431. [CrossRef]

31. Wang, G.; Yu, M.; Pal, J.S.; Mei, R.; Bonan, G.B.; Levis, S.; Thornton, P.E. On the development of a coupled regional climate-vegetation model RCM-CLM-CN-DV and its validation in Tropical Africa. Clim. Dyn. 2016, 46, 515-539. [CrossRef] 
32. Thuiller, W.; Midgley, G.F.; Hughes, G.O.; Bomhard, B.; Drew, G.; Rutherford, M.C.; Woodward, F.I. Endemic species and ecosystem sensitivity to climate change in Namibia. Glob. Chang. Biol. 2006, 12, 759-776. [CrossRef]

33. Mbatudde, M.; Mwanjololo, M.; Kakudidi, E.K.; Dalitz, H. Modelling the potential distribution of endangered Prunus africana (Hook.f.) Kalkm. in East Africa. Afr. J. Ecol. 2012, 50, 393-403. [CrossRef]

34. Idohou, R.; Assogbadjo, A.E.; Kakaï, R.G.; Peterson, A.T. Spatio-temporal dynamic of suitable areas for species conservation in West Africa: Eight economically important wild palms under present and future climates. Agrofor. Syst. 2017, 91, 527-540. [CrossRef]

35. Sarmento Cabral, J.; Jeltsch, F.; Thuiller, W.; Higgins, S.; Midgley, G.F.; Rebelo, A.G.; Rouget, M.; Schurr, F.M. Impacts of past habitat loss and future climate change on the range dynamics of South African Proteaceae. Divers. Distrib. 2013, 19, 363-376. [CrossRef]

36. Frenette-Dussault, C.; Shipley, B.; Meziane, D.; Hingrat, Y. Trait-based climate change predictions of plant community structure in arid steppes. J. Ecol. 2013, 101, 484-492. [CrossRef]

37. Tabet, S.; Belhemra, M.; François, L.; Arar, A. Evaluation by prediction of the natural range shrinkage of Quercus ilex L. in eastern Algeria. Forestist 2018, 68, 7-15. [CrossRef]

38. Ouled Belgacem, A.; Louhaichi, M. The vulnerability of native rangeland plant species to global climate change in the West Asia and North African regions. Clim. Chang. 2013, 119, 451-463. [CrossRef]

39. Hartig, F.; Dyke, J.; Hickler, T.; Higgins, S.I.; O'Hara, R.B.; Scheiter, S.; Huth, A. Connecting dynamic vegetation models to data-An inverse perspective. J. Biogeogr. 2012, 39, 2240-2252. [CrossRef]

40. Morin, X.; Thuiller, W. Comparing niche- and process-based models to reduce prediction uncertainty in species range shifts under climate change. Ecology 2009, 90, 1301-1313. [CrossRef] [PubMed]

41. Delire, C.; Ngomanda, A.; Jolly, D. Possible impacts of 21st century climate on vegetation in Central and West Africa. Glob. Planet. Chang. 2008, 64, 3-15. [CrossRef]

42. Zelazowski, P.; Malhi, Y.; Huntingford, C.; Sitch, S.; Fisher, J.B. Changes in the potential distribution of humid tropical forests on a warmer planet. Philos. Trans. R. Soc. Lond. A 2011, 369, 137-160. [CrossRef]

43. Budde, K.B.; Gonzalez-Martinez, S.C.; Hardy, O.J.; Heuertz, M. The ancient tropical rainforest tree Symphonia globulifera L. f. (Clusiaceae) was not restricted to postulated Pleistocene refugia in Atlantic Equatorial Africa. Heredity 2013, 111, 66-76. [CrossRef] [PubMed]

44. Feeley, K.; Silman, M. The data void in modelling current and future distributions of tropical species. Glob. Chang. Biol. 2011, 17, 626-630. [CrossRef]

45. François, L.; Delire, C.; Warnant, P.; Munhoven, G. Modelling the glacial-interglacial changes in the continental biosphere. Glob. Planet. Chang. 1998, 16-17, 37-52. [CrossRef]

46. François, L.; Ghislain, M.; Otto, D.; Micheels, A. Late Miocene vegetation reconstruction with the CARAIB model. Palaeogeogr. Palaeoclimatol. Palaeoecol. 2006, 238, 302-320. [CrossRef]

47. Dury, M.; Hambuckers, A.; Warnant, P.; Henrot, A.; Favre, E.; Ouberdous, M.; François, L. Responses of European forest ecosystems to 21st century climate: Assessing changes in interannual variability and fire intensity. iForest 2011, 4, 82-99. [CrossRef]

48. Dury, M. Modelling the Dynamics of European Ecosystems from the Early Holocene to the End of the 21st Century with the CARAIB Dynamic Vegetation Model. Ph.D. Thesis, Université de Liège, Liège, Belgium, 2015.

49. Raghunathan, N.; François, L.; Huynen, M.-C.; Oliveira, L.C.; Hambuckers, A. Modelling the distribution of key tree species used by lion tamarins in the Brazilian Atlantic forest under a scenario of future climate change. Reg. Environ. Chang. 2015, 15, 683-693. [CrossRef]

50. Raghunathan, N.; François, L.; Dury, M.; Hambuckers, A. Contrasting climate risks predicted by dynamic vegetation and ecological niche-based models applied to tree species in the Brazilian Atlantic Forest. Reg. Environ. Chang. 2018. [CrossRef]

51. Minet, J.; Laloy, E.; Tychon, B.; François, L. Bayesian inversions of a dynamic vegetation model at four European grassland sites. Biogeosciences 2015, 12, 2809-2829. [CrossRef]

52. Taylor, K.E.; Stouffer, R.J.; Meehl, G.A. An overview of CMIP5 and the experiment design. Bull. Am. Meteorol. Soc. 2012, 93, 485-498. [CrossRef]

53. Moss, R.H.; Edmonds, J.A.; Hibbard, K.A.; Manning, M.R.; Rose, S.K.; van Vuuren, D.P.; Carter, T.R.; Emori, S.; Kainuma, M.; Kram, T.; et al. The next generation of scenarios for climate change research and assessment. Nature 2010, 463, 747-756. [CrossRef] [PubMed] 
54. Hambuckers, A.; Huynen, M.-C.; Trolliet, F.; Jamar-Beudels, R.; Lafontaine, R.-M.; Robert, H.; Van Damme, P.; Baert, A.; Dendoncker, N.; Fontaine, C.; et al. BIOSERF: Sustainability of Tropical Forest Biodiversity and Services under Climate and Human Pressure; Final Report; Research Programme Science for a Sustainable Development; Belgian Science Policy: Brussels, Belgium, 2015.

55. Dauby, G.; Zaiss, R.; Blach-Overgaard, A.; Catarino, L.; Damen, T.; Deblauwe, V.; Dessein, S.; Dransfield, J.; Droissart, V.; Duarte, M.C.; et al. RAINBIO: A mega-database of tropical African vascular plants distributions. PhytoKeys 2016, 74, 1-18. [CrossRef]

56. Fayolle, A.; Swaine, M.D.; Bastin, J.-F.; Bourland, N.; Comiskey, J.A.; Dauby, G.; Doucet, J.-L.; Gillet, J.-F.; Gourlet-Fleury, S.; Hardy, O.J.; et al. Patterns of tree species composition across tropical African forests. J. Biogeogr. 2014, 41, 2320-2331. [CrossRef]

57. Kattge, J.; Díaz, S.; Lavorel, S.; Prentice, I.C.; Leadley, P.; Bönisch, G.; Garnier, E.; Westoby, M.; Reich, P.B.; Wright, I.J.; et al. TRY-A global database of plant traits. Glob. Chang. Biol. 2011, 17, 2905-2935. [CrossRef]

58. Kearsley, E.; de Haulleville, T.; Hufkens, T.; Kidimbu, K.; Toirambe, B.; Baert, G.; Huygens, D.; Kebede, Y.; Defourny, P.; Bogaert, J.; et al. Conventional tree height-diameter relationships significantly overestimate aboveground carbon stocks in the Central Congo Basin. Nat. Commun. 2013, 4, 2269. [CrossRef] [PubMed]

59. Kearsley, E.; Verbeeck, H.; Hufkens, K.; Van de Perre, F.; Doetterl, S.; Baert, G.; Beeckman, H.; Boeckx, P.; Huygens, D. Functional community structure of African monodominant Gilbertiodendron dewevrei forest influenced by local environmental filtering. Ecol. Evol. 2017, 7, 295-304. [CrossRef] [PubMed]

60. Kumar, P. The Economics of Ecosystems and Biodiversity: Ecological and Economic Foundations, 1st ed.; Earthscan: London, UK; Washington, DC, USA, 2010; p. 456. ISBN 9781136538803.

61. Harris, I.; Jones, P.D.; Osborn, T.J.; Lister, D.H. Updated high-resolution grids of monthly climatic observations-The CRU TS3.10 Dataset. Int. J. Climatol. 2014, 34, 623-642. [CrossRef]

62. Voldoire, A.; Sanchez-Gomez, E.; Salas y Mélia, D.; Decharme, B.; Cassou, C.; Sénési, S.; Valcke, S.; Beau, I.; Alias, A.; Chevallier, M.; et al. The CNRM-CM5.1 global climate model: Description and basic evaluation. Clim. Dyn. 2013, 40, 2091-2121. [CrossRef]

63. Giorgetta, M.A.; Jungclaus, J.; Reick, C.H.; Legutke, S.; Bader, J.; Böttinger, M.; Brovkin, V.; Crueger, T.; Esch, M.; Fieg, K.; et al. Climate and carbon cycle changes from 1850 to 2100 in MPI-ESM simulations for the Coupled Model Intercomparison Project phase 5. J. Adv. Model. Earth Syst. 2013, 5, 572-597. [CrossRef]

64. Gent, P.R.; Danabasoglu, G.; Donner, L.J.; Holland, M.M.; Hunke, E.C.; Jayne, S.R.; Lawrence, D.M.; Neale, R.B.; Rasch, P.J.; Vertenstein, M.; et al. The community climate system model version 4. J. Clim. 2011, 24, 4973-4991. [CrossRef]

65. Arora, V.K.; Scinocca, J.F.; Boer, G.J.; Christian, J.R.; Denman, K.L.; Flato, G.M.; Kharin, V.V.; Lee, W.G.; Merryfield, W.J. Carbon emission limits required to satisfy future representative concentration pathways of greenhouse gases. Geophys. Res. Lett. 2011, 38. [CrossRef]

66. Gordon, H.B.; O'Farrell, S.; Collier, M.; Dix, M.; Rotstayn, L.; Kowalczyk, E.; Hirst, T.; Watterson, I. The CSIRO Mk3.5 Climate Model; CAWCR Technical Report No. 21; The Centre for Australian Weather and Climate Research: Melbourne, Australia, 2010; p. 74. ISBN 978-1-921605-666.

67. Volodin, E.M.; Dianskii, N.A.; Gusev, A.V. Simulating present-day climate with the INMCM4.0 coupled model of the atmospheric and oceanic general circulations. Izv. Atmos. Ocean. Phys. 2010, 46, 414-431. [CrossRef]

68. Warnant, P.; François, L.; Strivay, D.; Gérard, J.-C. CARAIB—A global model of terrestrial biological productivity. Glob. Biogeochem. Cycles 1994, 8, 255-270. [CrossRef]

69. Gérard, J.-C.; Nemry, B.; François, L.; Warnant, P. The interannual change of atmospheric $\mathrm{CO}_{2}$ : Contribution of subtropical ecosystems? Geophys. Res. Lett. 1999, 26, 243-246. [CrossRef]

70. Henrot, A.-J.; Utescher, T.; Erdei, B.; Dury, M.; Hamon, N.; Ramstein, G.; Krapp, M.; Herold, N.; Goldner, A.; Favre, E.; et al. Middle Miocene climate and vegetation models and their validation with proxy data. Palaeogeogr. Palaeoclimatol. Palaeoecol. 2017, 467, 95-119. [CrossRef]

71. Otto, D.; Rasse, D.; Kaplan, J.; Warnant, P.; François, L. Biospheric carbon stocks reconstructed at the Last Glacial Maximum: Comparison between general circulation models using prescribed and computed sea surface temperatures. Glob. Planet. Chang. 2002, 33, 117-138. [CrossRef]

72. François, L.; Utescher, T.; Favre, E.; Henrot, A.; Warnant, P.; Micheels, A.; Erdei, B.; Suc, J.-P.; Cheddadi, R.; Mosbrugger, V. Modelling Late Miocene vegetation in Europe: Results of the CARAIB model and comparison with palaeovegetation data. Palaeogeogr. Palaeoclimatol. Palaeoecol. 2011, 304, 359-378. [CrossRef] 
73. Hubert, B.; François, L.; Warnant, P.; Strivay, D. Stochastic generation of meteorological variables and effects on global models of water and carbon cycles in vegetation and soils. J. Hydrol. 1998, 212-213, 317-334. [CrossRef]

74. Walker, A.P.; Beckerman, A.P.; Gu, L.; Kattge, J.; Cernusak, L.A.; Domingues, T.F.; Scales, J.C.; Wohlfahrt, G.; Wullschleger, S.D.; Woodward, F.I. The relationship of leaf photosynthetic traits $-V_{\mathrm{cmax}}$ and $J_{\max }-$ To leaf nitrogen, leaf phosphorus, and specific leaf area: A meta-analysis and modeling study. Ecol. Evol. 2014, 4, 3218-3235. [CrossRef] [PubMed]

75. Laurent, J.-M.; François, L.; Bar-Hen, A.; Bel, L.; Cheddadi, R. European Bioclimatic Affinity Groups: Data-model comparisons. Glob. Planet. Chang. 2008, 61, 28-40. [CrossRef]

76. Schenk, H.J.; Jackson, R.B. The global biogeography of roots. Ecol. Monogr. 2002, 72, 311-328. [CrossRef]

77. McGroddy, M.E.; Daufresne, T.; Hedin, L.O. Scaling of C:N:P Stoichiometry in Forests Worldwide: Implications of Terrestrial Redfield-Type Ratios. Ecology 2004, 85, 2390-2401. [CrossRef]

78. Warnant, P. Modélisation du Cycle du Carbone Dans la Biosphère Continentale à L'échelle Globale. Ph.D. Thesis, Université de Liège, Liège, Belgium, 1999.

79. Shipley, B. Trade-offs between net assimilation rate and specific leaf area in determining relative growth rate: Relationship with daily irradiance. Funct. Ecol. 2002, 16, 682-689. [CrossRef]

80. Meir, P.; Levy, P.E. Photosynthetic parameters from two contrasting woody vegetation types in West Africa. Plant Ecol. 2007, 192, 277-287. [CrossRef]

81. Wright, I.J.; Ackerly, D.D.; Bongers, F.; Harms, K.E.; Ibarra-Manriquez, G.; MartinezRamos, M.; Mazer, S.J.; Muller-Landau, H.C.; Paz, H.; Pitman, N.C.A.; et al. Relationships among ecologically important dimensions of plant trait variation in seven Neotropical forests. Ann. Bot. 2007, 99, 1003-1015. [CrossRef] [PubMed]

82. Fyllas, N.M.; Patino, S.; Baker, T.R.; Bielefeld Nardoto, G.; Martinelli, L.A.; Quesada, C.A.; Paiva, R.; Schwarz, M.; Horna, V.; Mercado, L.M.; et al. Basin-wide variations in foliar properties of Amazonian forest: Phylogeny, soils and climate. Biogeosciences 2009, 6, 2677-2708. [CrossRef]

83. Green, W. USDA PLANTS Compilation, version 1, 09-02-02. In NRCS: The PLANTS Database; National Plant Data Center: Baton Rouge, LA, USA, 2009.

84. Reich, P.B.; Wright, I.J.; Lusk, C.H. Predicting leaf physiology from simple plant and climate attributes: A global GLOPNET analysis. Ecol. Appl. 2007, 17, 1982-1988. [CrossRef] [PubMed]

85. Onoda, Y.; Westoby, M.; Adler, P.B.; Choong, A.M.F.; Clissold, F.J.; Cornelissen, J.H.C.; Diaz, S.; Dominy, N.J.; Elgart, A.; Enrico, L.; et al. Global patterns of leaf mechanical properties. Ecol. Lett. 2011, 14, 301-312. [CrossRef] [PubMed]

86. Kattge, J.; Knorr, W.; Raddatz, T.; Wirth, C. Quantifying photosynthetic capacity and its relationship to leaf nitrogen content for global-scale terrestrial biosphere models. Glob. Chang. Biol. 2009, 15, 976-991. [CrossRef]

87. Baraloto, C.; Paine, C.E.T.; Poorter, L.; Beauchene, J.; Bonal, D.; Domenach, A.-M.; Herault, B.; Patino, S.; Roggy, J.-C.; Chave, J. Decoupled leaf and stem economics in rainforest trees. Ecol. Lett. 2010, 13, 1338-1347. [CrossRef] [PubMed]

88. Domingues, T.F.; Meir, P.; Feldpausch, T.R.; Saiz, G.; Veenendaal, E.M.; Schrodt, F.; Bird, M.; Djagbletey, G.; Hien, F.; Compaore, H.; et al. Co-limitation of photosynthetic capacity by nitrogen and phosphorus in West Africa woodlands. Plant Cell Environ. 2010, 33, 959-980. [CrossRef] [PubMed]

89. Beer, C.; Reichstein, M.; Tomelleri, E.; Ciais, P.; Jung, M.; Carvalhais, N.; Rödenbeck, C.; Arain, M.A.; Baldocchi, D.; Bonan, G.B.; et al. Terrestrial gross carbon dioxide uptake: Global distribution and covariation with climate. Science 2010, 329, 834-838. [CrossRef] [PubMed]

90. Ainsworth, E.A.; Rogers, A. The response of photosynthesis and stomatal conductance to rising $\left[\mathrm{CO}_{2}\right]$ : Mechanisms and environmental interactions. Plant Cell Environ. 2007, 30, 258-270. [CrossRef] [PubMed]

91. Jones, A.G.; Scullion, J.; Ostle, N.; Levy, P.E.; Gwynn-Jones, D. Completing the FACE of elevated $\mathrm{CO}_{2}$ research. Environ. Int. 2014, 73, 252-258. [CrossRef] [PubMed]

92. Malhi, Y. The productivity, metabolism and carbon cycle of tropical forest vegetation. J. Ecol. 2012, 100, 65-75. [CrossRef]

93. Whittaker, R.H. Communities and Ecosystems, 2nd ed.; Collier-Macmillan: New York, NY, USA, 1975 ; p. 352. ISBN 978-0024273901.

94. Martinez-Yrizar, A.; Maass, J.M.; Perez-Jimenez, L.A.; Sarukhan, J. Net primary productivity of a tropical deciduous forest ecosystem in western Mexico. J. Trop. Ecol. 1996, 12, 169-175. [CrossRef] 
95. Poorter, L.; Castilho, C.V.; Schietti, J.; Oliveira, R.S.; Costa, F.R.C. Can traits predict individual growth performance? A test in a hyperdiverse tropical forest. New Phytol. 2018, 219, 109-121. [CrossRef] [PubMed]

96. Singer, A.; Johst, K.; Banitz, T.; Fowler, M.S.; Groeneveld, J.; Gutierrez, A.G.; Hartig, F.; Krug, R.M.; Liess, M.; Matlack, G.; et al. Community dynamics under environmental change: How can next generation mechanistic models improve projections of species distributions? Ecol. Model. 2016, 326, 63-74. [CrossRef]

97. Rogers, A.; Medlyn, B.E.; Dukes, J.S. Improving representation of photosynthesis in Earth System Models. New Phytol. 2014, 204, 12-14. [CrossRef] [PubMed]

98. Liu, Y.Y.; van Dijk, A.; de Jeu, R.; Canadell, J.G.; McCabe, M.; Evans, J.; Wang, G. Recent reversal in loss of global terrestrial biomass. Nat. Clim. Chang. 2015, 5, 470-474. [CrossRef]

99. Smith, N.G.; Dukes, J.S. Plant respiration and photosynthesis in global-scale models: Incorporating acclimation to temperature and $\mathrm{CO}_{2}$. Glob. Chang. Biol. 2013, 19, 45-63. [CrossRef] [PubMed]

100. Wu, M.; Schurgers, G.; Rummukainen, M.; Smith, B.; Samuelsson, P.; Jansson, C.; Siltberg, J.; May, W. Vegetation-Climate feedbacks modulate rainfall patterns in Africa under future climate change. Earth Syst. Dyn. 2016, 7, 627-647. [CrossRef]

101. Haxeltine, A.; Prentice, I.C. A general model for the light-use efficiency of primary production. Funct. Ecol. 1996, 10, 551-561. [CrossRef]

102. Bush, M.B.; Flenley, J.R.; Gosling, W.D. Tropical Rainforest Responses to Climate Change, 2nd ed.; Springer: Dordrecht, The Netherlands, 2011; p. 454. ISBN 978-3-642-05383-2.

103. James, R.; Washington, R.; Rowell, D.P. Implications of global warming for the climate of African rainforests. Philos. Trans. R. Soc. B 2013, 368, 20120298. [CrossRef] [PubMed]

104. Rammig, A.; Jupp, T.; Thonicke, K.; Tietjen, B.; Heinke, J.; Ostberg, S.; Lucht, W.; Cramer, W.; Cox, P. Estimating the risk of Amazonian forest dieback. New Phytol. 2010, 187, 694-706. [CrossRef] [PubMed]

105. Huntingford, C.; Zelazowski, P.; Galbraith, D.; Mercado, L.M.; Sitch, S.; Fisher, R.; Lomas, M.; Walker, A.P.; Jones, C.D.; Booth, B.B.B.; et al. Simulated resilience of tropical rainforests to $\mathrm{CO}_{2}$-induced climate change. Nat. Geosci. 2013, 6, 268-273. [CrossRef]

106. Gopalakrishnan, R.; Jayaraman, M.; Swarnim, S.; Chaturvedi, R.; Bala, G.; Ravindranath, N. Impact of climate change at species level: A case study of teak in India. Mitig. Adapt. Strateg. Glob. Chang. 2011, 16, 199-209. [CrossRef]

107. Lloyd, J.; Farquhar, G. Effects of rising temperatures and $\left[\mathrm{CO}_{2}\right]$ on the physiology of tropical forest trees. Philos. Trans. R. Soc. Lond. B 2008, 363, 1811-1817. [CrossRef] [PubMed]

108. Scheiter, S.; Higgins, S.I. Impacts of climate change on the vegetation of Africa: An adaptive dynamic vegetation modelling approach. Glob. Chang. Biol. 2009, 15, 2224-2246. [CrossRef]

109. Malhi, Y.; Aragão, L.E.O.C.; Galbraith, D.; Huntingford, C.; Fisher, R.; Zelazowski, P.; Sitch, S.; McSweeney, C.; Meir, P. Exploring the likelihood and mechanism of a climate-change-induced dieback of the Amazon rainforest. Proc. Natl. Acad. Sci. USA 2009, 106, 20610-20615. [CrossRef] [PubMed]

110. Yu, M.; Wang, G.; Parr, D.; Ahmed, K.F. Future changes of the terrestrial ecosystem based on a dynamic vegetation model driven with RCP8.5 climate projections from 19 GCMs. Clim. Chang. 2014, 127, 257-271. [CrossRef]

111. Bastin, J.F. Estimating the Aboveground Biomass of Central African Tropical Forests at the Tree, the Canopy and the Region Level. Ph.D. Thesis, Université de Liège, Liège, Belgium, 2014.

112. Santiago, L.S.; Bonal, D.; De Guzman, M.E.; Ávila-Lovera, E. Drought Survival Strategies of Tropical Trees. In Tropical Tree Physiology; Goldstein, G., Santiago, L., Eds.; Springer: Cham, Switzerland, 2016; Volume 6, pp. 243-258. ISBN 978-90-8585-534-7.

113. Scheiter, S.; Savadogo, P. Ecosystem management can mitigate vegetation shifts induced by climate change in West Africa. Ecol. Model. 2016, 332, 19-27. [CrossRef]

114. Davies-Barnard, T.; Valdes, P.J.; Singarayer, J.S.; Wiltshire, A.J.; Jones, C.D. Quantifying the relative importance of land cover change from climate and land use in the representative concentration pathways. Glob. Biogeochem. Cycles 2015, 29, 842-853. [CrossRef]

115. Fontaine, P. Introduction: The Social Sciences in a Cross-Disciplinary Age. J. Hist. Behav. Sci. 2015, 51, 1-9. [CrossRef] [PubMed]

116. O'Brien, K.L. Climate change and social transformations: Is it time for a quantum leap? Wiley Interdiscip. Rev. Clim. Chang. 2016, 7, 618-626. [CrossRef] 
117. Trolliet, F.; Forget, P.-M.; Huynen, M.-C.; Hambuckers, A. Forest cover, hunting pressure, and fruit availability influence seed dispersal in a forest-savanna mosaic in the Congo Basin. Biotropica 2017, 49, 337-345. [CrossRef]

118. García, C.; Klein, A.K.; Jordano, P. Dispersal processes driving plant movement: Challenges for understanding and predicting range shifts in a changing world. J. Ecol. 2017, 105, 1-5. [CrossRef] 